Vol. 5 (1996): 431-447.

\title{
Uptake of heavy metals by plants from airborne deposition and polluted soils
}

\author{
Toivo Yläranta
}

Agricultural Research Centre of Finland, Institute of Soils and Environment, FIN-31600 Jokioinen, Finland

The concentrations of sulphur, zinc, copper, lead and cadmium in spring wheat grain and straw, Italian rye grass, timothy and lettuce were studied in a three-year field experiment conducted in southern Finland near a copper-nickel smelter and at nonpolluted control sites.

A pot experiment with copper- and nickel-contaminated soils and with a nonpolluted soil as the control was conducted to determine the copper and nickel concentrations in soils phytotoxic for plants. Forty, 200 or $1000 \mathrm{mg}$ of copper or nickel as cloride was added to 2 litres of soil. The nickel and copper concentrations in the shoots of oats were measured.

The zinc, copper, lead, cadmium and nickel concentrations varied between different plant species and also between experimental years.

Near the smelter, the uptake of nickel by different plant species was very effective, as was copper uptake by lettuce, timothy and Italian rye grass. The same applied to the zinc and cadmium uptake of plants grown on plots. Nickel, cadmium and copper were easily accumulated by plants from air deposition.

In the pot experiment, high nickel concentrations in soil were more phytotoxic for oats than were high copper concentrations. In acidic soil, nickel and copper concentrations lower than 20 and 100 $\mathrm{mg} / \mathrm{kg}$ of soil, respectively, decreased the dry matter yield of oats shoots. Liming clearly decreased copper and nickel phytotoxity. In the most highly contaminated soil, the addition of $\mathrm{Cu} 20 \mathrm{mg} / \mathrm{kg}$ of soil decreased the yield of oats shoots.

Key words: pollution, bulk deposition, dry deposition, copper-nickel smelter

\section{Introduction}

The most pronounced form of pollution from the metallurgical industry comprises emissions to the atmosphere. There is, however, a scarcity of information on the proportion of elements in de- position that is accumulated by plants from the air direct and the proportion taken up from the soil on which they grow.

In Finland, there are only a few places where heavy metal emissions are high enough to cause problems for agricultural plant production. One of these is the Outokumpu works at Harjavalta, 


\section{AGRICULTURAL AND FOOD SCIENCE IN FINLAND}

Yläranta, T. Uptake of heavy metals by plants from airborne deposition and polluted soils

southwestern Finland. The main heavy metal source at the Harjavalta Works is a copper-nickel smelter. In the $1980 \mathrm{~s}$ it accounted for about $1 \%$ of the world production of copper and $2 \%$ of that of nickel. At the same time the total annual emissions of some elements and $\mathrm{SO}_{2}$ were as follows: $\mathrm{SO}_{2} 7500 \mathrm{t}$, particles $2200 \mathrm{t}, \mathrm{Cu} 300 \mathrm{t}$, $\mathrm{Ni} 70$ t, Zn 200 t, Pb $50 \mathrm{t}$ and Cd 1.9 t (Provincial Government of Turku \& Pori). The emissions were partly stack and partly non-point emissions. There were also some other smaller industrial emission sources of $\mathrm{SO}_{2}$ and heavy metals.

The purpose of this study was to determine the accumulation by plants of heavy metals from airborne deposition and polluted soils. The Harjavalta Works were established in 1945 but both production capacity and production methods have changed many times since then. Thus, the adjacent soils have been receiving heavy metals over a period of five decades.

The experiments were carried out at Harjavalta and at nonpolluted control sites at Jokioinen in 1985, 1986 and 1988. Further information was collected with a pot experiment conducted in polluted Harjavalta soil and nonpolluted control soil in 1990. In the latter experiment copper and nickel, the elements causing the heaviest pollution of Harjavalta soils, were added to the soils in concentrations intended to yield phytotoxic copper and nickel levels.

\section{Material and methods}

\section{Experimental fields}

The experiment was carried out in 1985 and 1986 at seven experimental sites in southern Finland. Two of these were reference sites located at Jokioinen, in a clean rural area close to the $\mathrm{Ag}$ ricultural Research Centre of Finland:

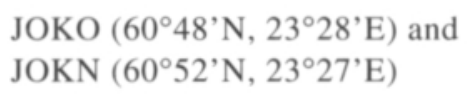

The other five experimental sites were near the Outokumpu works $\left(61^{\circ} 19^{\prime} \mathrm{N}, 22^{\circ} 08^{\prime} \mathrm{E}\right)$ at Harjavalta (TAM, POH, PAP and TUP) and at Kokemäki (SAT) 90-100 km northwest of Jokioinen:

TAM $800 \mathrm{~m}$ from the smelter to $91^{\circ}$

$\mathrm{POH} 1300 \mathrm{~m}$ to $312^{\circ}$

PAP $2700 \mathrm{~m}$ to $132^{\circ}$

TUP $4400 \mathrm{~m}$ to $117^{\circ}$

SAT $8500 \mathrm{~m}$ to $126^{\circ}$

In 1988, the experiment was carried out at three sites only:

JOKA $\left(60^{\circ} 48^{\prime} \mathrm{N}, 23^{\circ} 28^{\prime} \mathrm{E}\right)$ at Jokioinen

TAMI $800 \mathrm{~m}$ from the Harjavalta smelter to $91^{\circ}$ and

JOHA $1500 \mathrm{~m}$ from the smelter to $51^{\circ}$.

In 1988, a new experimental site, JOHA, was established for the collection of data on the effect of different wind directions from the Harjavalta Works on the heavy metal concentrations of plants.

Plots without any replicates, $3 \times 3 \mathrm{~m}^{2}$ in size and growing spring wheat (Triticum aestivum, cv. Ruso), timothy (Phleum pratense, cv. Tarmo), Italian rye grass (Lolium multiflorum L., cv. Amenda) or Australian lettuce (Lactuca sativa), were established at each experimental site. A schematic diagram of the experimental field has been presented by Yläranta (1995).

The plough layer $(0-25 \mathrm{~cm})$ of experimental soils was sandy except at $\mathrm{POH}$, where it was loam, and at JOK, where it was sandy clay loam (Table 1). On JOKO, JOKN, JOKA and POH fields, the particle size distribution was finer and in other fields coarser in the deeper layer (25$60 \mathrm{~cm}$ ) than in the plough layer.

Yläranta (1995) has described the use of pots on the plots and the fertilization, management and harvest techniques of the experimental plants. Timothy was sown and managed like Italian rye grass. In 1985 and 1986, rye grass and timothy were cut three times. Lettuce was sown and harvested twice in both years. On JOKA, TAMI and JOHA fields one wheat and lettuce yield and three rye grass yields were harvested in 1988. 


\section{AGRICULTURAL AND FOOD SCIENCE IN FINLAND}

Vol. 5 (1996): 431-447.

Table 1. Soil sample means $(0-25 \mathrm{~cm})$ of different experimental sites and pots for $\mathrm{pH}\left(\mathrm{CaCl}_{2}\right)$, organic carbon content $(\mathrm{OC}, \%)$ and particle size distribution (clay $<0.002$, silt $0.002-0.02$, fine sand $0.02-0.2$ and coarse sand 0.2-2 mm) at experimental sites in 1985 and 1986, 1988 and 1990 (pot experiment).

\begin{tabular}{lrrrrrr}
\hline & & & & & \multicolumn{2}{c}{ Sand } \\
& $\mathrm{pH}$ & $\mathrm{OC}$ & Clay & Silt & Fine & Coarse \\
\hline 1985 and 1986 & & & & & & \\
JOKO & 5.9 & 1.8 & 18 & 10 & 34 & 38 \\
JOKN & 5.7 & 2.0 & 9 & 5 & 62 & 24 \\
TAM & 6.0 & 2.6 & 4 & 7 & 63 & 26 \\
POH & 4.9 & 2.8 & 27 & 36 & 19 & 18 \\
PAP & 5.3 & 2.5 & 8 & 14 & 62 & 16 \\
TUP & 6.7 & 2.0 & 5 & 13 & 51 & 31 \\
SAT & 5.8 & 1.7 & 10 & 14 & 72 & 1 \\
1988 & & & & & & \\
JOKA & 6.3 & 2.8 & 26 & 16 & 26 & 23 \\
TAMI & 5.7 & 2.5 & 3 & 7 & 63 & 27 \\
JOHA & 5.8 & 1.5 & 4 & 7 & 73 & 16 \\
Pot soils & & & & & & \\
Sandy soil & 5.8 & 6.1 & 5 & 6 & 62 & 27 \\
Carex peat & 6.0 & 37 & - & - & - & - \\
1990 & & & & & & \\
Pot experiment & & & & & & \\
EPO & 4.2 & 4.3 & 39 & 20 & 38 & 3 \\
PAP & 4.9 & 2.5 & 8 & 15 & 63 & 15 \\
TAM & 5.6 & 2.6 & 4 & 8 & 56 & 33 \\
\hline
\end{tabular}

\section{Deposition sampling and analytical methods}

Two NILU (Norsk Institut for Luftforskning, Lillestrøm, Norway) deposit gauges with 2-litre bottles, one for nitrogen (NSP) and one for sulphur, phosphorus and the heavy metals zinc, copper, lead, cadmium and nickel (ME), were placed on each experimental field. In 1988, dry deposition was collected at TAMI on a $47-\mathrm{mm}$ teflon filter from June 21 to September 27 (Millipore FALP04700, pore size $1 \mu \mathrm{m}$ ).

The zinc, copper, lead, cadmium and nickel in the experimental soils were extracted with acid ammonium acetate-EDTA and aqua regia and analysed with ICP-AES ( $\mathrm{Zn}, \mathrm{Cu})$ and ET-AAS $(\mathrm{Pb}, \mathrm{Cd}, \mathrm{Ni})$. The zinc, copper, calcium, magne- sium, potassium and phosphorus concentrations in the plant samples were determined with ICPAES and the concentrations of lead, cadmium and nickel with ET-AAS,

Total nitrogen in deposition was determined on NSP samples, and sulphur, phosphorus, zinc, copper, nickel, lead and cadmium were determined on ME samples.

The dry deposition of sulphur, zinc, copper, lead, cadmium and nickel on the teflon filters was determined on the $\mathrm{HNO}_{3}-\mathrm{H}_{2} \mathrm{O}_{2}-\mathrm{HCl}$ digestion solution, that of lead and cadmium with ETAAS and that of other elements with ICP-AES.

Yläranta (1995) has decribed the bulk and dry deposition sampling and analytical methods in detail. The analytical laboratory that carried out the elemental analysis is participating in the European intercalibration network, EC/BCR. 


\section{AGRICULTURAL AND FOOD SCIENCE IN FINLAND}

Yläranta, T. Uptake of heavy metals by plants from airborne deposition and polluted soils

\section{Pot experiment}

Two litres of wet EPO clay soil (1672 g of dry matter, Table 1) and $2500 \mathrm{~g}$ of wet sandy PAP and TAM soils (2033 g of dry matter) were weighed into 3-litre HD polyethylene pots. TAM and PAP soils were taken from the fields where the TAM, TAMI and PAP field experiments were carried out; EPO soil was taken from a nonpolluted field in a rural area $250 \mathrm{~km}$ north of Jokioinen.

There were four replicates, the experimental plan being as follows:

1. Control, no $\mathrm{Cu}$ or $\mathrm{Ni}$ addition

2. $\mathrm{Cu}$ addition, $40 \mathrm{mg} / \mathrm{pot}$

3. Cu $200 \mathrm{mg}$

4. $\mathrm{Cu} 1000 \mathrm{mg}$

5. $\mathrm{Ni}$ addition, $40 \mathrm{mg} /$ pot

6. Ni $200 \mathrm{mg}$

7. $\mathrm{Ni} 1000 \mathrm{mg}$

In addition, the treatments in EPO soils were limed with $\mathrm{Ca}(\mathrm{OH})_{2}$ to increase the $\mathrm{pH}\left(\mathrm{CaCl}_{2}\right)$ by $1.5 \mathrm{pH}$ unit (Mäntylahti and Yläranta 1980). The total number of pots in the experiment was 112.

The fertilizers mixed into the whole amount of soil in the pot were pure chemicals (Merck, p.a.) dissolved in deionized water as follows:

$$
\begin{array}{lrl}
\mathrm{N} & 470 \mathrm{mg} & \left(\mathrm{NH}_{4}\right)_{2} \mathrm{HPO}_{4}, \mathrm{NH}_{4} \mathrm{NO}_{3} \\
\mathrm{P} & 80 \mathrm{mg} & \left(\mathrm{NH}_{4}\right)_{2} \mathrm{HPO}_{4} \\
\mathrm{~K} & 350 \mathrm{mg} & \mathrm{KCl}_{2} \mathrm{~K}_{2} \mathrm{SO}_{4} \\
\mathrm{Mg} & 90 \mathrm{mg} & \mathrm{MgCl}_{2} \times 6 \mathrm{H}_{2} \mathrm{O} \\
\mathrm{Ca} & 60 \mathrm{mg} & \mathrm{CaCl}_{2} \times 2 \mathrm{H}_{2} \mathrm{O} \\
\mathrm{S} & 80 \mathrm{mg} & \mathrm{K}_{2} \mathrm{SO}_{4}, \mathrm{MnSO}_{4} \times \mathrm{H}_{2} \mathrm{O}, \\
& & \mathrm{ZnSO}_{4} \times 7 \mathrm{H}_{2} \mathrm{O}, \\
& & \mathrm{CuSO}_{4} \times 5 \mathrm{H}_{2} \mathrm{O} \\
\mathrm{Mn} & 3.3 \mathrm{mg} & \mathrm{MnSO}_{4} \times \mathrm{H}_{2} \mathrm{O} \\
\mathrm{Zn} & 2.3 \mathrm{mg} & \mathrm{ZnSO}_{4} \times 7 \mathrm{H}_{2} \mathrm{O} \\
\mathrm{Cu} & 2.6 \mathrm{mg} & \mathrm{CuSO}_{4} \times 5 \mathrm{H}_{2} \mathrm{O} \\
\mathrm{Fe} & 2.0 \mathrm{mg} & \mathrm{FeNa}_{-} \mathrm{EDTA}^{-} \\
\mathrm{Mo} & 0.4 \mathrm{mg} & \mathrm{Na}_{2} \mathrm{MoO}_{4} \times \mathrm{H}_{2} \mathrm{O} \\
\mathrm{B} & 0.4 \mathrm{mg} & \mathrm{H}_{3} \mathrm{BO}_{3}
\end{array}
$$

From each pot, $250 \mathrm{ml}$ of soil was put aside and $20 \mathrm{ml}$ of copper or nickel solution was mixed with the rest of the soil. Copper and nickel solutions were prepared from pure chemicals (Merck p.a.), $\mathrm{Cu}$ from $\mathrm{CuCl}_{2} \times 2 \mathrm{H}_{2} \mathrm{O}$ and $\mathrm{Ni}$ from $\mathrm{NiCl}_{2} \times 6 \mathrm{H}_{2} \mathrm{O}$. Seventeen seeds of oats (cv. Veli) were sown on May 29, 1990 in each pot and covered with $250 \mathrm{ml}$ of soil. The shoots of oats were cut on July 9,1990 , dried at $60^{\circ} \mathrm{C}$ and ground in a hammer mill.

\section{Results and discussion}

\section{Soil characteristics}

The concentrations of HAAC-EDTA-extractable zinc, copper, lead and nickel were notably lower in the unpolluted soils (JOKO, JOKN and JOKA) than in the other experimental soils (Table 2). The concentrations of zinc, copper and nickel were clearly higher at Harjavalta, near the copper-nickel smelter (TAM, POH, PAP, TAMI and JOHA) than in uncontaminated Finnish soils (Erviö et al. 1990). The lead concentrations in Harjavalta soils were likewise mostly higher than those in Finnish soils on average. Some copper pollution from the Harjavalta smelter can also be seen in the top layer of POH soil (Table 2). Moreover the concentration of cadmium is higher in the soils at Harjavalta than in uncontaminated soils. However, the high heavy metal concentrations were recorded only in the top soil $(0-25 \mathrm{~cm})$, implying that only a small fraction of the deposited metals had been leached and accumulated under the plough layer.

Aqua regia (AR) extracts the heavy metals in soils almost totally. The AR values of zinc and copper in polluted Harjavalta soils were clearly higher than those in "clean" JOKN soils. Element concentrations in fine-textured soils are commonly higher than those in coarse mineral soils. The higher clay content of JOKO and JOKA soils may explain why their zinc concentrations were higher than those in TAM soil. The sampling sites TAM and TAMI were close to each other. Thus only a large natural variation 
Vol. 5 (1996): 431-447.

Table 2. Soil sample means for HAAC-EDTA and aqua regia-extractable $\mathrm{Zn}, \mathrm{Cu}, \mathrm{Pb}, \mathrm{Cd}, \mathrm{Ni}$ (mg/kg of dry soil).

\begin{tabular}{|c|c|c|c|c|c|c|c|c|c|c|c|}
\hline \multirow[t]{2}{*}{ Site } & \multirow{2}{*}{$\begin{array}{c}\text { Layer, } \\
\mathrm{cm}\end{array}$} & \multicolumn{5}{|c|}{ HAAC-EDTA } & \multicolumn{5}{|c|}{ AQUA REGIA } \\
\hline & & $\mathrm{Zn}$ & $\mathrm{Cu}$ & $\mathrm{Pb}$ & $\mathrm{Cd}$ & $\mathrm{Ni}$ & $\mathrm{Zn}$ & $\mathrm{Cu}$ & $\mathrm{Pb}$ & $\mathrm{Cd}$ & $\mathrm{Ni}$ \\
\hline \multicolumn{12}{|c|}{1985,1986} \\
\hline \multirow[t]{2}{*}{ JOKO } & $0-25$ & 2.3 & 3.3 & 2.3 & 0.16 & 0.8 & 55 & 16 & 8 & 0.56 & 21 \\
\hline & $25-50$ & 0.7 & 3.0 & 2.2 & 0.32 & 1.2 & & & & & \\
\hline \multirow[t]{2}{*}{ JOKN } & $0-25$ & 0.9 & 1.3 & 2.7 & 0.14 & 0.8 & 13 & 8 & 9 & 0.26 & 13 \\
\hline & $25-50$ & 0.2 & 0.6 & 0.6 & 0.08 & 0.2 & & & & & \\
\hline \multirow[t]{2}{*}{ TAM } & $0-25$ & 16 & 190 & 8.5 & 0.60 & 17 & 61 & 260 & 17 & 0.79 & 17 \\
\hline & $25-50$ & 3.5 & 18 & 1.5 & 0.12 & 1.0 & & & & & \\
\hline \multirow[t]{2}{*}{$\mathrm{POH}$} & $0-25$ & 9.9 & 82 & 5.1 & 0.42 & 12 & 116 & 161 & 22 & 0.58 & 40 \\
\hline & $25-50$ & 0.8 & 2.9 & 1.4 & 0.18 & 0.6 & & & & & \\
\hline \multirow[t]{2}{*}{ PAP } & $0-25$ & 22 & 38 & 5.6 & 0.28 & 3.9 & 80 & 67 & 15 & 0.41 & 15 \\
\hline & $25-50$ & 2.1 & 1.6 & 0.8 & 0.05 & 0.3 & & & & & \\
\hline \multirow[t]{2}{*}{ TUP } & $0-25$ & 3.3 & 12 & 2.5 & 0.13 & 1.3 & 21 & 19 & 7 & 0.21 & 6 \\
\hline & $25-50$ & 0.3 & 0.7 & 0.3 & 0.05 & 0.1 & & & & & \\
\hline \multirow[t]{2}{*}{ SAT } & $0-25$ & 0.8 & 6.1 & 1.7 & 0.17 & 0.7 & 26 & 12 & 11 & 0.19 & 11 \\
\hline & $25-50$ & 0.3 & 1.0 & 0.5 & 0.09 & 0.3 & & & & & \\
\hline \multicolumn{12}{|c|}{ Pot soil } \\
\hline \multicolumn{12}{|c|}{ Sandy soil } \\
\hline & $0-25$ & 1.6 & 2.2 & 1.1 & 0.10 & 0.4 & 25 & 8 & 8 & 0.23 & 9 \\
\hline \multicolumn{12}{|l|}{1988} \\
\hline \multirow[t]{2}{*}{ JOKA } & $0-25$ & 2.5 & 4.5 & 2.6 & 0.09 & 1.0 & 82 & 20 & 14 & 0.22 & 23 \\
\hline & $30-60$ & 0.4 & 3.2 & 1.7 & 0.02 & 1.1 & & & & & \\
\hline \multirow[t]{2}{*}{ TAMI } & $0-25$ & 12 & 142 & 5.6 & 0.41 & 17 & 320 & 252 & 14 & 0.66 & 59 \\
\hline & $25-50$ & 1.6 & 1.2 & 0.5 & 0.05 & 0.6 & & & & & \\
\hline \multirow[t]{2}{*}{ JOHA } & $0-25$ & 14 & 72 & 3.7 & 0.32 & 10 & 55 & 127 & 10 & 0.44 & 30 \\
\hline & $25-50$ & 0.5 & 1.9 & 0.1 & 0.02 & 0.1 & & & & & \\
\hline \multicolumn{12}{|c|}{ Pot soil } \\
\hline \multicolumn{12}{|c|}{ Carex peat } \\
\hline & $0-25$ & 9.5 & 13 & 1.4 & 0.23 & 5.7 & 49 & 42 & 18 & 0.47 & 20 \\
\hline \multicolumn{12}{|l|}{1990} \\
\hline \multicolumn{12}{|c|}{ Pot exp. } \\
\hline EPO & $0-25$ & 1.4 & 6.1 & - & - & 4.3 & & & & & \\
\hline PAP & $0-25$ & 21 & 35 & - & - & 4.2 & & & & & \\
\hline TAM & $0-25$ & 14 & 104 & - & - & 16 & & & & & \\
\hline
\end{tabular}

in element concentrations in this field can explain the large differences between zinc and nickel concentrations in these soils. The concentrations of AR-extractable zinc and lead in Harjavalta soils were very small compared with those in a polluted soil near an old lead-zinc mine in Spain, for instance (Ansorena et al. 1995). According to the preliminary standards for soil pollution in Poland (Fotyma and Terelak 1994), soils at Harjavalta are heavily polluted with copper, very slightly polluted with zinc, nickel and cadmium and unpolluted with lead.

The heavy metals in contaminated soils were more readily extractable into HAAC-EDTA than the respective concentrations extracted with AR. On average, $70 \%$ of AR-extractable cadmium, $50 \%$ of copper and $4-30 \%$ of zinc were extractable into HAAC-EDTA. Relatively speaking, the 


\section{AGRICULTURAL AND FOOD SCIENCE IN FINLAND}

Yläranta, T. Uptake of heavy metals by plants from airborne deposition and polluted soils

highest HAAC-EDTA-extractable heavy metal concentrations were measured on the coarsest soils (TAM, TAMI and JOHA). Smaller fractions of AR-extractable cadmium $(40 \%), \mathrm{Cu}(20 \%)$ and $\mathrm{Zn}$ (3-19\%) were extracted into HAACEDTA from nonpolluted, JOKO, JOKN, JOKA and pot soils than from polluted Harjavalta soils. $\mathrm{Zn}$ and $\mathrm{Ni}$ were easily extractable into HAACEDTA from Carex peat pot soil; copper, however, was extractable only with difficulty. Extractable Ni concentrations were very low in nonpolluted mineral soils.

\section{Deposition}

The annual bulk deposition of zinc, copper, lead and cadmium at Harjavalta and Jokioinen (JOKO, JOKN) can be estimated from the sum of the values measured during the growing period from June 13, 1985 to October 8, 1985 and from October 8, 1985 to May 28, 1986 (Table 3 ). Copper and cadmium deposition at some Harjavalta sites was tens of times that at Jokioinen, which can be considered a "nonpolluted" rural area in southern Finland.

The bulk deposition of zinc, copper, lead, cadmium and nickel at Harjavalta was really high when compared with Swedish heavy metal deposition values (Andersson and Gustafson 1988). The lead deposition measured here at TAM, POH, PAP, TAMI and JOHA was often also many times higher than that measured alongside roads at Jokioinen and at Nurmijärvi in 1987 and 1988 (Yläranta 1995). The main source of heavy metal deposition at Harjavalta was the copper-nickel smelter. Nickel deposition, too, was therefore high at Harjavalta as measured during the growing period in 1988 (Table 3 ).

Differences in zinc and lead deposition between Harjavalta and Jokioinen were not as large as in other elements. However, fairly high zinc and lead depositions were measured at JOKO in 1986 (Table 3). These values are probably due to the emissions from a small industrial point source at Jokioinen.

The most sensitive biological instruments for measuring the deposition of heavy metals in terrestrial ecosystems are certain mosses (Hertz 1991). Using the moss technique Rühling et al. (1987, 1992) measured copper and nickel concentration of over 28 and $30 \mathrm{mg} / \mathrm{kg}$ in dry moss samples in the Harjavalta region. These values are the highest ever measured in northern Europe including Denmark, Estonia, Finland, Iceland, Latvia, Lithuania, Norway, Sweden and adjacent areas of Russia.

Sulphur emissions from the Outokumpu Harjavalta Works during the experimental period from 1985 to 1986 amounted to about 7500 metric tons of $\mathrm{SO}_{2}$. In spite of this, the annual bulk deposition of sulphur at experimental sites at Harjavalta was only some kilograms per hectare (Table 3), being almost equal to the values measured at Jokioinen. The only available explanation is that most of the $\mathrm{SO}_{2}$ emissions were spread over a large area instead of being deposited locally. The annual nitrogen deposition, too, was only some kilograms per hectare, presumably because there are no special $\mathrm{NO}$ or $\mathrm{NO}_{2}$ sources at Harjavalta.

The lead concentration in air (Fig. 1) was ten times and the cadmium concentration tens of times that of the "background" values (Yläranta 1995). The lead concentration was still, on average, clearly lower than that measured in air at 13 sites in or near London, UK in 1985 and 1986 (Jensen and Laxen 1987). Between the end of June and the beginning of July the lead concentration had a very clear peak. At Harjavalta, occasional peak concentrations were also typical of bulk depositions. The simultaneous lead and cadmium peaks were obviously due to unexpected malfunctions in industrial processes. The mean concentrations of other elements in dry deposition at TAMI, the lead and cadmium deposition at the same experimental site and the values measured from June 21 to September 27, $1988200 \mathrm{~m}$ from a road at Jokioinen (JO II, Yläranta 1995) $200 \mathrm{~m}$ from a road were as follows $\left(\mathrm{ng} \mathrm{m}^{-3}\right)$ :

$\begin{array}{lrrrrrr} & \mathrm{S} & \mathrm{Zn} & \mathrm{Cu} & \mathrm{Pb} & \mathrm{Cd} & \mathrm{Ni} \\ \text { TAMI } & 880 & 140 & 30 & 73 & 2.5 & 13 \\ \text { JOII } & 720 & 10 & 1.6 & 7.9 & 0.06 & 4.2\end{array}$


Vol. 5 (1996): 431-447.

Table 3. Precipitation (Prec.) and bulk deposition of some elements at the experimental sites in 1985, 1986 and 1988.

\begin{tabular}{|c|c|c|c|c|c|c|c|c|}
\hline \multirow{2}{*}{$\begin{array}{l}\text { Site and time } \\
\text { period }\end{array}$} & \multirow{2}{*}{$\begin{array}{l}\text { Prec. } \\
\text { mm }\end{array}$} & $\mathrm{N}$ & S & $\mathrm{Zn}$ & $\mathrm{Cu}$ & $\mathrm{Pb}$ & $\mathrm{Cd}$ & $\mathrm{Ni}$ \\
\hline & & \multicolumn{2}{|c|}{$\mathrm{kg} \mathrm{ha}^{-1}$} & \multicolumn{5}{|c|}{$\mathrm{g} \mathrm{ha}^{-1}$} \\
\hline \multicolumn{9}{|c|}{$13.6-8.10 .1985$} \\
\hline JOKO & 243 & 2.2 & 2.8 & 66 & 16 & 16 & 0.14 & $\left.-^{*}\right)$ \\
\hline JOKN & 250 & 2.7 & 2.7 & 20 & 201 & 14 & 0.15 & - \\
\hline TAM & 243 & 2.7 & 3.6 & 190 & 1100 & 170 & 4.3 & - \\
\hline $\mathrm{POH}$ & 232 & 2.9 & 3.7 & 92 & 410 & 46 & 2.6 & - \\
\hline PAP & 253 & 2.2 & 2.6 & 95 & 230 & 170 & 1.3 & - \\
\hline TUP & 236 & 1.9 & 2.3 & 41 & 78 & 20 & 0.46 & - \\
\hline SAT & 240 & 2.4 & 2.3 & 36 & 43 & 25 & 0.33 & - \\
\hline \multicolumn{9}{|c|}{$8.10 .1985-28.5 .1986$} \\
\hline JOKO & 208 & 3.4 & 2.7 & 67 & 6 & 42 & 0.23 & - \\
\hline JOKN & 165 & 2.9 & 2.3 & 15 & 5 & 12 & 0.18 & - \\
\hline TAM & 224 & 3.9 & 4.4 & 420 & 2600 & 130 & 10.4 & - \\
\hline $\mathrm{POH}$ & 227 & 5.8 & 6.5 & 320 & 1200 & 83 & 5.3 & - \\
\hline PAP & 219 & 3.3 & 2.9 & 160 & 290 & 230 & 1.7 & - \\
\hline TUP & 228 & 2.8 & 2.5 & 48 & 110 & 23 & 0.79 & - \\
\hline SAT & 277 & 3.6 & 2.8 & 37 & 60 & 22 & 0.44 & - \\
\hline \multicolumn{9}{|c|}{$28.5-22.10 .1986$} \\
\hline JOKO & 349 & 3.1 & 3.2 & 26 & 7 & 21 & 0.16 & - \\
\hline JOKN & 334 & 3.0 & 3.2 & 18 & 8 & 15 & 0.14 & - \\
\hline TAM & 314 & 3.1 & 4.8 & 260 & 2200 & 82 & 31.7 & - \\
\hline $\mathrm{POH}$ & 312 & 3.2 & 4.6 & 150 & 1000 & 58 & 6.9 & - \\
\hline PAP & 291 & 2.6 & 3.2 & 120 & 410 & 42 & 2.6 & - \\
\hline TUP & 298 & 2.4 & 2.8 & 29 & 97 & 20 & 3.0 & - \\
\hline SAT & 300 & 2.9 & 2.9 & 34 & 79 & 40 & 15.8 & - \\
\hline \multicolumn{9}{|c|}{$31.5-27.9 .1988$} \\
\hline JOKA & 243 & 2.1 & 2.2 & 20 & 33 & 8 & 0.17 & 24 \\
\hline TAMI & 315 & 1.8 & 3.3 & 140 & 1200 & 62 & 3.1 & 490 \\
\hline JOHA & 311 & 1.9 & 2.7 & 79 & 410 & 28 & 1.0 & 165 \\
\hline
\end{tabular}

*) not measured

Although the concentrations of elements in dry deposition are not given in " $\mathrm{g}$ ha ${ }^{-1}$ ", we can deduce from the values shown that the dry deposition of most elements at TAMI has been very low compared with the bulk deposition (Table 3). Exceptions to this "rule" are sulphur and zinc. Heavy metal concentrations in the air were clearly higher than in the "clean" background area at Jokioinen. It is surprising that sulphur deposition was equally high at both sites.

\section{Metal accumulation by plants}

\section{Field experiments}

In 1985 and 1986, the yields varied clearly from growing site to growing site but not very much within the pots grown in plots (Table 4-9). No abnormal differences in calcium, magnesium, potassium, phosphorus or sulphur concentrations were seen between plants grown on plots and those grown in pots. Therefore, except for sulphur, these figures are omitted from the final results. 
Yläranta, T. Uptake of heavy metals by plants from airborne deposition and polluted soils

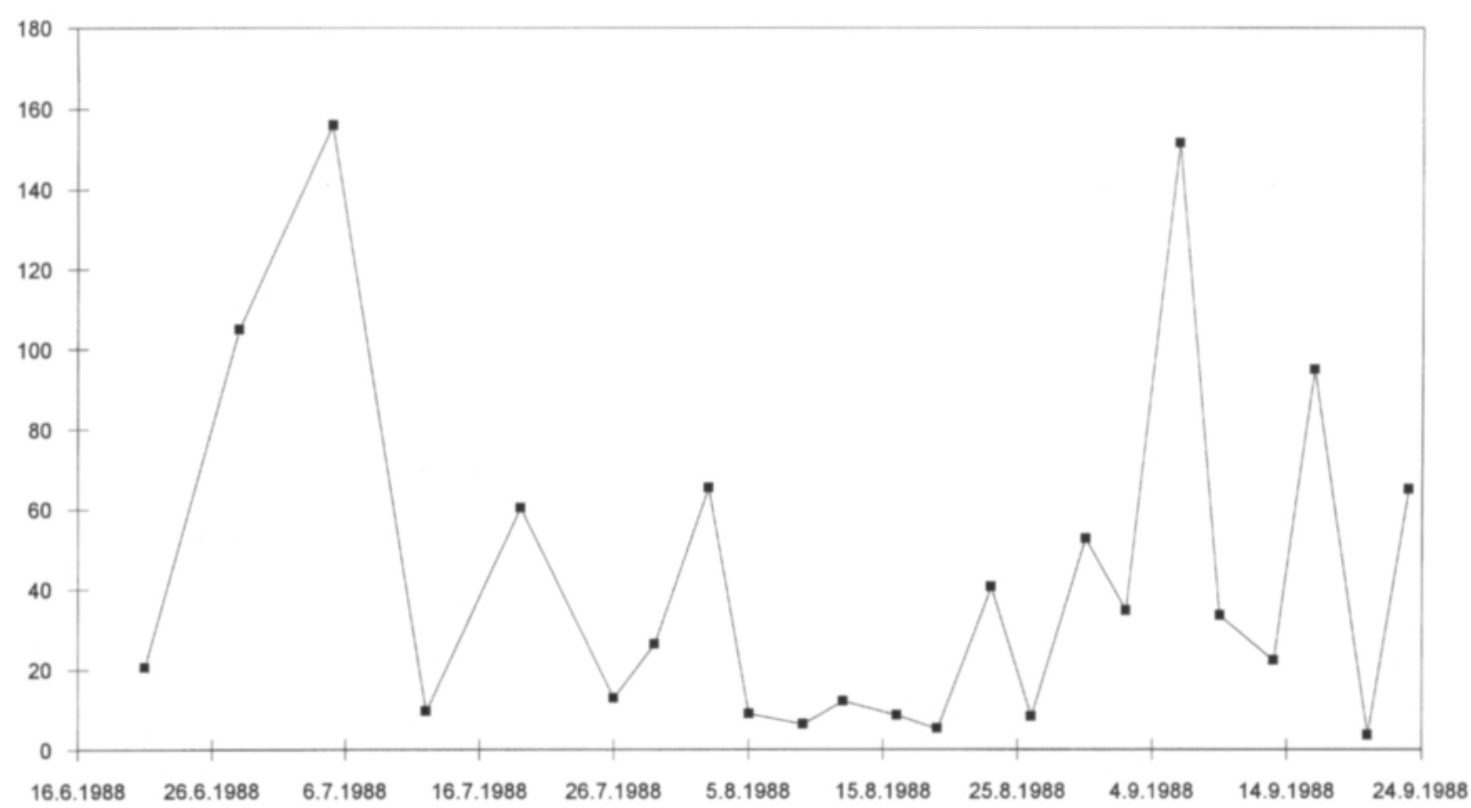

Fig. 1. Dry deposition of $\mathrm{Pb}\left(\mathrm{ng} \mathrm{m}^{-3}\right)$ measured on dust filters. Each point represents sampling for 3-4 days. The squares are joined by a line to ease readability.

The concentrations of zinc, copper, lead, cadmium and nickel varied between different plant species and also to some extent between the ex- perimental years. The differences in the sulphur concentrations of plants were smaller than were those in heavy metals.

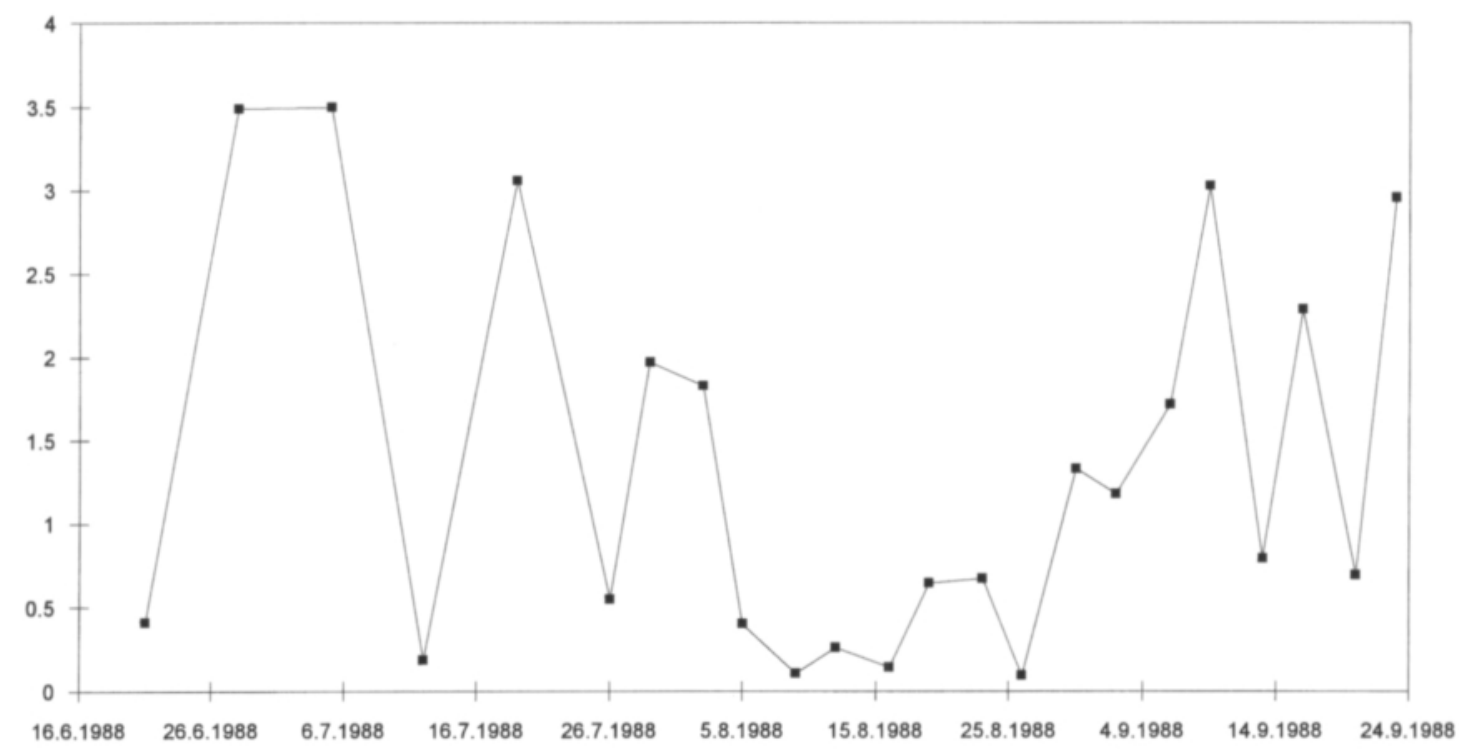

Fig. 2. Dry deposition of $\mathrm{Cd}\left(\mathrm{ng} \mathrm{m}^{-3}\right)$ measured on dust filters. Otherwise as in Fig. 1. 
Vol. 5 (1996): 431-447.

Table 4. Mean dry matter yield, g/plot (Y) or pot (A), S, and heavy metal concentrations ( $\mathrm{mg} / \mathrm{kg}$ of dry matter) of first yield of lettuce at Jokioinen (JOKO) and (JOKN), Harjavalta (TAM, POH, PAP, TUP) and Kokemäki (SAT) in 1985 and 1986.

\begin{tabular}{|c|c|c|c|c|c|c|c|c|}
\hline \multicolumn{2}{|c|}{ Lettuce } & JOKO & JOKN & TAM & $\mathrm{POH}$ & PAP & TUP & SAT \\
\hline \multicolumn{9}{|l|}{1985} \\
\hline Yield & $\mathrm{Y}$ & 1131 & 1354 & 1437 & 856 & 1420 & 1127 & 1256 \\
\hline Yield & A & $11.5^{\mathrm{bc}}$ & $11.3^{\mathrm{bc}}$ & $11.9^{b}$ & $19.7^{a}$ & $7.5^{\mathrm{d}}$ & $8.9^{\text {cd }}$ & $10.9^{\mathrm{bc}}$ \\
\hline $\mathrm{Zn}$ & $\mathrm{Y}$ & $35^{d}$ & $28^{\mathrm{d}}$ & $96^{c}$ & $193^{\circ}$ & $141^{b}$ & $30^{d}$ & $30^{d}$ \\
\hline $\mathrm{Zn}$ & A & $43^{a b c c}$ & $34^{c}$ & $36^{\mathrm{bc}}$ & $52^{\mathrm{ab}}$ & $55^{\mathrm{a}}$ & $34^{c}$ & $40^{\text {abc }}$ \\
\hline $\mathrm{Cu}$ & $\mathrm{Y}$ & $4.7^{e}$ & $3.7^{\mathrm{c}}$ & $67^{2}$ & $60^{2}$ & $40^{b}$ & $14^{c}$ & $11^{\mathrm{c}}$ \\
\hline $\mathrm{Cu}$ & A & $8.1^{\mathrm{c}}$ & $4.0^{\mathrm{c}}$ & $33^{\mathrm{ab}}$ & $40^{a}$ & $29^{b}$ & $7.1^{\mathrm{c}}$ & $7.3^{c}$ \\
\hline $\mathrm{Pb}$ & $\mathrm{Y}$ & $0.33^{\mathrm{c}}$ & $0.28^{e}$ & $1.75^{b}$ & $3.55^{\mathrm{a}}$ & $0.76^{c}$ & $0.44^{c}$ & $0.46^{c}$ \\
\hline $\mathrm{Pb}$ & A & $0.31^{\mathrm{c}}$ & $0.17^{c}$ & $0.80^{b}$ & $2.81^{a}$ & $0.75^{\mathrm{c}}$ & $0.19^{\mathrm{c}}$ & $0.22^{\mathrm{c}}$ \\
\hline Cd & $\mathrm{Y}$ & $0.65^{f}$ & $1.52^{\mathrm{c}}$ & $3.25^{b}$ & $5.41^{\mathrm{a}}$ & $1.12^{\mathrm{de}}$ & $1.00^{e}$ & $1.35^{\mathrm{cd}}$ \\
\hline Cd & A & $0.51^{\mathrm{bc}}$ & $0.45^{\mathrm{c}}$ & $0.53^{\mathrm{bc}}$ & $0.70^{a}$ & $0.62^{\mathrm{ab}}$ & $0.51^{\mathrm{be}}$ & $0.55^{\mathrm{bc}}$ \\
\hline $\mathrm{Ni}$ & $\mathrm{Y}$ & $0.90^{d}$ & $1.06^{d}$ & $11.4^{b}$ & $36.0^{\mathrm{a}}$ & $4.88^{\mathrm{c}}$ & $1.58^{\mathrm{d}}$ & $1.78^{\mathrm{d}}$ \\
\hline $\mathrm{Ni}$ & A & $0.82^{\text {cd }}$ & $0.46^{d}$ & $3.22^{\mathrm{b}}$ & $6.04^{\mathrm{a}}$ & $1.58^{c}$ & $0.44^{d}$ & $0.58^{\mathrm{cd}}$ \\
\hline $\mathrm{S}$ & $\mathrm{Y}$ & $2.29^{e}$ & $2.73^{d}$ & $3.70^{\mathrm{b}}$ & $4.76^{\mathrm{a}}$ & $4.58^{\mathrm{a}}$ & $2.67^{\mathrm{d}}$ & $3.21^{\mathrm{c}}$ \\
\hline$S$ & A & $3.59^{\mathrm{b}}$ & $3.31^{\mathrm{b}}$ & $3.79^{\mathrm{b}}$ & $2.60^{\mathrm{c}}$ & $4.19^{\mathrm{a}}$ & $3.38^{b}$ & $3.33^{b}$ \\
\hline \multicolumn{9}{|l|}{1986} \\
\hline Yield & Y & 2910 & 2025 & 1930 & 995 & 1786 & 2390 & 1981 \\
\hline Yield & A & $20.5^{a}$ & $18.2^{\mathrm{ab}}$ & $13.5^{\mathrm{bc}}$ & $21.1^{\mathrm{a}}$ & $11.1^{\mathrm{c}}$ & $16.2^{\mathrm{abc}}$ & $16.8^{\mathrm{abc}}$ \\
\hline $\mathrm{Zn}$ & $\mathrm{Y}$ & $34^{c}$ & $35^{\mathrm{c}}$ & $88^{b}$ & $184^{a}$ & $85^{b}$ & $30^{c}$ & $32^{\mathrm{c}}$ \\
\hline $\mathrm{Zn}$ & A & $50^{\mathrm{a}}$ & $41^{\mathrm{bc}}$ & $45^{\mathrm{ab}}$ & $49^{a}$ & $40^{\mathrm{bc}}$ & $35^{c}$ & $35^{c}$ \\
\hline $\mathrm{Cu}$ & $\mathrm{Y}$ & $5.3^{\mathrm{c}}$ & $4.4^{\mathrm{c}}$ & $47^{\mathrm{a}}$ & $49^{\mathrm{a}}$ & $49^{\mathrm{a}}$ & $15^{b}$ & $22^{b}$ \\
\hline $\mathrm{Cu}$ & A & $8.8^{\text {cd }}$ & $6.4^{d}$ & $31^{\mathrm{b}}$ & $58^{\mathrm{a}}$ & $27^{b}$ & $13^{\text {cd }}$ & $16^{c}$ \\
\hline $\mathrm{Pb}$ & $\mathrm{Y}$ & $0.31^{\mathrm{c}}$ & $0.17^{\mathrm{c}}$ & $0.80^{\mathrm{b}}$ & $2.81^{\mathrm{a}}$ & $0.75^{c}$ & $0.19^{c}$ & $0.22^{\mathrm{c}}$ \\
\hline $\mathrm{Pb}$ & A & $0.22^{\mathrm{c}}$ & $0.30^{c}$ & $1.94^{\mathrm{a}}$ & $2.23^{\mathrm{a}}$ & $2.09^{\mathrm{a}}$ & $0.56^{\mathrm{a}}$ & $1.28^{\mathrm{b}}$ \\
\hline $\mathrm{Cd}$ & $\mathrm{Y}$ & $0.53^{\mathrm{c}}$ & $1.25^{\mathrm{e}}$ & $3.50^{\mathrm{b}}$ & $4.94^{\mathrm{a}}$ & $0.76^{c}$ & $0.93^{c}$ & $1.34^{\mathrm{c}}$ \\
\hline $\mathrm{Cd}$ & A & $0.54^{b}$ & $0.60^{b}$ & $0.96^{\mathrm{a}}$ & $0.77^{\mathrm{ab}}$ & $0.68^{b}$ & $0.55^{b}$ & $0.57^{b}$ \\
\hline $\mathrm{Ni}$ & $\mathrm{Y}$ & $0.86^{\text {ef }}$ & $0.61^{f}$ & $29.3^{b}$ & $51.6^{\mathrm{a}}$ & $13.4^{\mathrm{c}}$ & $4.66^{\mathrm{dfe}}$ & $5.28^{\mathrm{d}}$ \\
\hline $\mathrm{Ni}$ & A & $0.41^{e}$ & $0.30^{e}$ & $18.8^{b}$ & $27.9^{\mathrm{a}}$ & $6.47^{\mathrm{c}}$ & $3.58^{\mathrm{d}}$ & $3.36^{\mathrm{d}}$ \\
\hline S & $\mathrm{Y}$ & $2.52^{\mathrm{c}}$ & $2.61^{c}$ & $3.54^{b}$ & $4.38^{\mathrm{a}}$ & $2.87^{\mathrm{c}}$ & $2.78^{\mathrm{c}}$ & $2.70^{\mathrm{c}}$ \\
\hline S & A & $2.59^{\mathrm{c}}$ & $2.74^{\mathrm{bc}}$ & $3.55^{\mathrm{a}}$ & $2.46^{\mathrm{c}}$ & $2.66^{c}$ & $3.05^{b}$ & $2.45^{\mathrm{c}}$ \\
\hline
\end{tabular}

Means not marked with a common letter differ from each other at the 1\% significance level (Tukey's HSD, Honestly Significant Difference test). The plots and pots were tested separately.

In most cases the element concentrations were highest at the experimental sites TAM and POH (Table 4-8) and TAMI and JOHA (Table 9). The element concentrations at $\mathrm{POH}$ often differed from those measured in the "clean area" and at JOKO, JOKN and JOKA, but also from those measured at TUP and SAT, both of which are farther from the Outokumpu Harjavalta Works than are TAM, POH, PAP, TAMI and
JOHA. The zinc, copper, lead, nickel and sulphur concentrations in timothy grown at JOKO and JOKN were at the same level but the cadmium concentrations were at a somewhat higher level than the reported average in Finland (Mäkelä-Kurtto et al. 1993).

In all cases nickel accumulation by different plant species was intense at Harjavalta. Copper was effectively accumulated by lettuce, timothy 


\section{AGRICULTURAL AND FOOD SCIENCE IN FINLAND}

Yläranta, T. Uptake of heavy metals by plants from airborne deposition and polluted soils

Table 5. Mean dry matter yield, g/plot (Y) or pot (A), S, and heavy metal concentrations (mg/kg of dry matter) of spring wheat grain and straw at Jokioinen (JOKO) and (JOKN), Harjavalta (TAM, POH, PAP, TUP) and Kokemäki (SAT) in 1985.

\begin{tabular}{|c|c|c|c|c|c|c|c|c|}
\hline & & JOKO & JOKN & TAM & $\mathrm{POH}$ & PAP & TUP & SAT \\
\hline \multicolumn{9}{|l|}{ Grain } \\
\hline Yield & $\mathrm{Y}$ & 2364 & 2740 & 3003 & 2529 & 3784 & 4746 & 3650 \\
\hline Yield & A & $20.7^{b}$ & $22.0^{b}$ & $29.5^{a}$ & $31.7^{\mathrm{a}}$ & $30.2^{a}$ & $20.3^{b}$ & $21.3^{b}$ \\
\hline $\mathrm{Zn}$ & $\mathrm{Y}$ & $30^{c}$ & $29^{c}$ & $62^{a}$ & $64^{a}$ & $49^{b}$ & $35^{c}$ & $31^{\mathrm{c}}$ \\
\hline $\mathrm{Zn}$ & A & $33^{a b}$ & $34^{a b}$ & $32^{a b}$ & $32^{\mathrm{ab}}$ & $30^{b}$ & $35^{a}$ & 32 abx \\
\hline $\mathrm{Cu}$ & $\mathrm{Y}$ & $2.3^{\mathrm{e}}$ & $3.4^{e}$ & $10^{a}$ & $8.2^{b}$ & $6.2^{\mathrm{c}}$ & $6.2^{\mathrm{c}}$ & $4.6^{d}$ \\
\hline $\mathrm{Cu}$ & A & $3.7^{\mathrm{c}}$ & $5.2^{\mathrm{b}}$ & $7.1^{\mathrm{a}}$ & $5.3^{b}$ & $5.1^{\mathrm{b}}$ & $5.1^{b}$ & $4.6^{b}$ \\
\hline $\mathrm{Pb}$ & $\mathrm{Y}$ & $0.053^{c}$ & $0.018^{f}$ & $0.072^{a}$ & $0.045^{d}$ & $0.064^{b}$ & $0.032^{\circ}$ & $0.030^{e}$ \\
\hline $\mathrm{Pb}$ & A & $0.015^{f}$ & $0.021^{e}$ & $0.073^{b}$ & $0.035^{c}$ & $0.083^{a}$ & $0.027^{d}$ & $0.015^{f}$ \\
\hline $\mathrm{Cd}$ & $\mathrm{Y}$ & $0.029^{f}$ & $0.031^{f}$ & $0.25^{a}$ & $0.17^{b}$ & $0.063^{c}$ & $0.059^{d}$ & $0.037^{e}$ \\
\hline $\mathrm{Cd}$ & A & $0.034^{d}$ & $0.031^{e}$ & $0.057^{\mathrm{a}}$ & $0.048^{b}$ & $0.038^{c}$ & $0.046^{b}$ & $0.034^{d}$ \\
\hline $\mathrm{Ni}$ & $\mathrm{Y}$ & $0.14^{b}$ & $0.10^{b}$ & $13.2^{\mathrm{a}}$ & $13.5^{a}$ & $0.54^{b}$ & $0.40^{b}$ & $0.20^{b}$ \\
\hline $\mathrm{Ni}$ & A & $0.10^{b}$ & $0.10^{b}$ & $3.28^{\mathrm{a}}$ & $3.67^{\mathrm{a}}$ & $0.28^{b}$ & $0.24^{b}$ & $0.10^{b}$ \\
\hline $\mathrm{S}$ & $\mathrm{Y}$ & $1.67^{\mathrm{a}}$ & $1.69^{\mathrm{a}}$ & $1.69^{a}$ & $1.75^{\mathrm{a}}$ & $1.76^{\mathrm{a}}$ & $1.70^{\mathrm{a}}$ & $1.68^{\mathrm{a}}$ \\
\hline $\mathrm{S}$ & A & $1.98^{a b c}$ & $2.03^{\mathrm{ab}}$ & $2.09^{\mathrm{a}}$ & $1.92^{b c}$ & $1.83^{c}$ & $2.04^{\mathrm{ab}}$ & $1.94^{\text {abx }}$ \\
\hline \multicolumn{9}{|l|}{ Straw } \\
\hline Yield & $\mathrm{Y}$ & 4049 & 4830 & 5266 & 8538 & 5614 & 5487 & 2740 \\
\hline Yield & A & $30.1^{b}$ & $36.0^{\mathrm{a}}$ & $39.7^{a}$ & $38.0^{\mathrm{a}}$ & $40.0^{\mathrm{a}}$ & $34.8^{\mathrm{ab}}$ & $35.8^{a b}$ \\
\hline $\mathrm{Zn}$ & $\mathrm{Y}$ & $8.7^{d}$ & $7.3^{d}$ & $97.3^{\mathrm{a}}$ & $73.8^{b}$ & $39.2^{\mathrm{c}}$ & $12.8^{\mathrm{d}}$ & $8.2^{\mathrm{d}}$ \\
\hline $\mathrm{Zn}$ & A & $11.7^{b}$ & $9.9^{b}$ & $24.9^{\mathrm{a}}$ & $24.0^{\mathrm{a}}$ & $12.5^{b}$ & $10.3^{b}$ & $9.7^{\mathrm{b}}$ \\
\hline $\mathrm{Cu}$ & $\mathrm{Y}$ & $1.8^{\mathrm{c}}$ & $2.1^{\mathrm{c}}$ & $74.7^{a}$ & $36.5^{b}$ & $6.5^{c}$ & $6.5^{c}$ & $3.7^{\mathrm{c}}$ \\
\hline $\mathrm{Cu}$ & A & $2.9^{c}$ & $3.4^{c}$ & $172.6^{a}$ & $78.9^{b}$ & $9.9^{c}$ & $7.8^{\mathrm{c}}$ & $5.3^{c}$ \\
\hline $\mathrm{Pb}$ & $\mathrm{Y}$ & $0.79^{c}$ & $0.78^{c}$ & $3.25^{\mathrm{a}}$ & $2.11^{b}$ & $2.77^{\mathrm{ab}}$ & $1.21^{\mathrm{c}}$ & $0.59^{c}$ \\
\hline $\mathrm{Pb}$ & A & $0.93^{c}$ & $1.02^{c}$ & $4.92^{\mathrm{a}}$ & $3.47^{b}$ & $4.98^{a}$ & $1.37^{c}$ & $0.71^{\mathrm{c}}$ \\
\hline $\mathrm{Cd}$ & $\mathrm{Y}$ & $0.057^{e}$ & $0.058^{\mathrm{c}}$ & $0.976^{a}$ & $0.647^{b}$ & $0.126^{\mathrm{c}}$ & $0.103^{\mathrm{c}}$ & $0.077^{c}$ \\
\hline $\mathrm{Cd}$ & A & $0.072^{b}$ & $0.059^{b}$ & $0.334^{a}$ & $0.259^{a}$ & $0.083^{b}$ & $0.075^{b}$ & $0.060^{b}$ \\
\hline $\mathrm{Ni}$ & $\mathrm{Y}$ & $0.34^{\mathrm{c}}$ & $0.16^{c}$ & $31.90^{\mathrm{a}}$ & $12.04^{b}$ & $1.42^{\mathrm{c}}$ & $1.30^{\mathrm{c}}$ & $1.18^{\mathrm{c}}$ \\
\hline $\mathrm{Ni}$ & A & $0.22^{\mathrm{c}}$ & $0.16^{c}$ & $52.0^{\mathrm{a}}$ & $19.92^{b}$ & $1.96^{\mathrm{c}}$ & $1.32^{\mathrm{e}}$ & $0.44^{c}$ \\
\hline $\mathrm{S}$ & $\mathrm{Y}$ & $0.82^{\mathrm{c}}$ & $0.91^{c}$ & $1.69^{\mathrm{a}}$ & $1.53^{\mathrm{a}}$ & $1.60^{\mathrm{a}}$ & $1.51^{\mathrm{a}}$ & $1.11^{b}$ \\
\hline $\mathrm{S}$ & A & $1.11^{\mathrm{c}}$ & $1.17^{\mathrm{c}}$ & $1.64^{a}$ & $1.50^{a b}$ & $1.34^{\mathrm{bc}}$ & $1.50^{\mathrm{ab}}$ & $1.52^{\mathrm{ab}}$ \\
\hline
\end{tabular}

Statistical tests as in Table 4.

and Italian rye grass, as were zinc and cadmium by plants grown on plots.

The accumulation of heavy metals by plants from the soil and airborne deposition could be evaluated with the experimental design used. The soil at Harjavalta was found to have been polluted since 1945 by emissions from various industrial processes, mainly from the smelter, whereas pot soils were not polluted (Table 2).

There were differences within the plants grown in different soils and at different sites; this, too, affected the element concentrations in plants. However, using the concentrations of elements measured in plants grown at clean JOKO, JOKN and JOKA sites we can compare the accumulation by plants of elements from the soil on the plot with that from airborne deposition.

The mobility of copper and lead in plants is slight (e.g. Gorlach and Gambuś 1992), as shown by the low copper and lead concentrations of wheat grain (Tables 5 and 6). The root tissue is the primary site of accumulation of copper but 
Vol. 5 (1996): 431-447.

Table 6. Mean dry matter yield, g/plot (Y) or pot (A), S, and heavy metal concentrations (mg/kg of dry matter) of spring wheat grain and straw at Jokioinen (JOKO) and (JOKN), Harjavalta (TAM, POH, PAP, TUP) and Kokemäki (SAT) in 1986.

\begin{tabular}{|c|c|c|c|c|c|c|c|c|}
\hline & & JOKO & JOKN & TAM & $\mathrm{POH}$ & PAP & TUP & SAT \\
\hline \multicolumn{9}{|l|}{ Grain } \\
\hline Yield & $\mathrm{Y}$ & 2503 & 2675 & 3509 & 2475 & 4870 & 3194 & 2487 \\
\hline Yield & A & $16.4^{\mathrm{ab}}$ & $10.1^{b}$ & $22.7^{\mathrm{a}}$ & $21.3^{a}$ & $20.1^{\mathrm{a}}$ & $16.8^{\mathrm{a}}$ & $22.1^{\mathrm{a}}$ \\
\hline $\mathrm{Zn}$ & $\mathrm{Y}$ & $32^{\text {cd }}$ & $31^{\mathrm{cd}}$ & $67^{a}$ & $68^{a}$ & $44^{b}$ & $37^{\mathrm{bc}}$ & $27^{\mathrm{d}}$ \\
\hline $\mathrm{Zn}$ & A & $42^{b}$ & $57^{a}$ & $36^{c}$ & $44^{b}$ & $35^{\circ}$ & $35^{c}$ & $35^{\circ}$ \\
\hline $\mathrm{Cu}$ & $\mathrm{Y}$ & $3.2^{\mathrm{d}}$ & $2.3^{e}$ & $9.6^{\mathrm{a}}$ & $8.0^{b}$ & $5.0^{\mathrm{c}}$ & $5.9^{\mathrm{c}}$ & $5.0^{c}$ \\
\hline $\mathrm{Cu}$ & A & $3.5^{\mathrm{b}}$ & $3.6^{\mathrm{bc}}$ & $6.5^{a}$ & $6.1^{\mathrm{a}}$ & $4.1^{b}$ & $3.2^{\mathrm{c}}$ & $3.1^{\mathrm{c}}$ \\
\hline $\mathrm{Pb}$ & $\mathrm{Y}$ & $0.044^{d}$ & $0.077^{a}$ & $0.053^{b}$ & $0.075^{\mathrm{a}}$ & $0.046^{d}$ & $0.049^{c}$ & $0.051^{b c}$ \\
\hline $\mathrm{Pb}$ & A & $0.045^{\mathrm{a}}$ & $0.022^{\mathrm{d}}$ & $0.039^{b}$ & $0.038^{b}$ & $0.027^{\mathrm{c}}$ & $0.029^{\mathrm{c}}$ & $0.011^{\mathrm{e}}$ \\
\hline $\mathrm{Cd}$ & $\mathrm{Y}$ & $0.030^{f}$ & $0.061^{\mathrm{c}}$ & $0.304^{a}$ & $0.193^{b}$ & $0.042^{\mathrm{d}}$ & $0.060^{c}$ & $0.035^{e}$ \\
\hline $\mathrm{Cd}$ & A & $0.033^{f}$ & $0.081^{b}$ & $0.099^{\mathrm{a}}$ & $0.078^{c}$ & $0.037^{e}$ & $0.045^{d}$ & $0.046^{d}$ \\
\hline $\mathrm{Ni}$ & $\mathrm{Y}$ & $0.040^{b}$ & $0.106^{b}$ & $11.30^{\mathrm{a}}$ & $9.69^{\mathrm{a}}$ & $0.65^{b}$ & $0.538^{b}$ & $0.38^{b}$ \\
\hline $\mathrm{Ni}$ & A & $0.032^{\mathrm{c}}$ & $0.078^{c}$ & $3.66^{a}$ & $2.79^{b}$ & $0.412^{\mathrm{c}}$ & $0.300^{c}$ & $0.128^{\mathrm{c}}$ \\
\hline $\mathrm{S}$ & $\mathrm{Y}$ & $1.84^{\mathrm{a}}$ & $1.79^{\mathrm{ab}}$ & $1.79 \mathrm{ab}$ & $1.68^{\mathrm{bc}}$ & $1.55^{\mathrm{c}}$ & $1.77 \mathrm{ab}$ & $1.72^{\mathrm{ab}}$ \\
\hline S & A & $1.85^{\mathrm{be}}$ & $1.98^{\mathrm{ab}}$ & $1.87^{\mathrm{bc}}$ & $2.12^{\mathrm{a}}$ & $1.93 \mathrm{abc}$ & $2.03^{\mathrm{ab}}$ & $1.71^{\mathrm{c}}$ \\
\hline \multicolumn{9}{|l|}{ Straw } \\
\hline Yield & $\mathrm{Y}$ & 2904 & 3281 & 5331 & 3193 & 5236 & 4500 & 3363 \\
\hline Yield & A & $23.9^{b}$ & $20.6^{b}$ & $33.9^{\mathrm{a}}$ & $38.0^{\mathrm{a}}$ & $27.8^{\mathrm{ab}}$ & $25.3^{\mathrm{ab}}$ & $27.2^{\mathrm{ab}}$ \\
\hline $\mathrm{Zn}$ & $\mathrm{Y}$ & $8.5^{c}$ & $7.8^{\mathrm{c}}$ & $105^{a}$ & $69^{b}$ & $23^{\mathrm{c}}$ & $10^{c}$ & $6.8^{\mathrm{c}}$ \\
\hline $\mathrm{Zn}$ & A & $12^{b}$ & $20^{\mathrm{a}}$ & $20^{\mathrm{a}}$ & $14^{b}$ & $13^{b}$ & $11^{b}$ & $12^{b}$ \\
\hline $\mathrm{Cu}$ & $\mathrm{Y}$ & $1.9^{c}$ & $1.8^{\mathrm{c}}$ & $32.0^{\mathrm{a}}$ & $19.7^{b}$ & $6.8^{c}$ & $4.9^{\mathrm{c}}$ & $6.1^{\mathrm{c}}$ \\
\hline $\mathrm{Cu}$ & A & $2.6^{\mathrm{d}}$ & $2.7^{\mathrm{d}}$ & $25.6^{\mathrm{a}}$ & $21.0^{b}$ & $8.6^{\mathrm{c}}$ & $4.8^{\text {cd }}$ & $5.5^{\text {cd }}$ \\
\hline $\mathrm{Pb}$ & $\mathrm{Y}$ & $0.412^{\mathrm{c}}$ & $0.531^{\mathrm{c}}$ & $2.19^{\mathrm{a}}$ & $1.391^{\mathrm{b}}$ & $0.638^{c}$ & $0.572^{\mathrm{c}}$ & $0.795^{\mathrm{c}}$ \\
\hline $\mathrm{Pb}$ & A & $0.456^{b}$ & $0.491^{b}$ & $1.71^{\mathrm{a}}$ & $1.58^{\mathrm{a}}$ & $0.789^{b}$ & $0.505^{b}$ & $0.646^{b}$ \\
\hline $\mathrm{Cd}$ & $\mathrm{Y}$ & $0.055^{c}$ & $0.101^{\mathrm{c}}$ & $1.39^{\mathrm{a}}$ & $0.958^{b}$ & $0.128^{\mathrm{c}}$ & $0.132^{\mathrm{c}}$ & $0.127^{\mathrm{c}}$ \\
\hline $\mathrm{Cd}$ & A & $0.084^{e}$ & $0.128^{\mathrm{c}}$ & $0.485^{\mathrm{a}}$ & $0.388^{b}$ & $0.125^{c}$ & $0.109^{\mathrm{c}}$ & $0.130^{b}$ \\
\hline $\mathrm{Ni}$ & $\mathrm{Y}$ & $0.054^{\mathrm{c}}$ & $0.054^{\mathrm{c}}$ & $11.47^{\mathrm{a}}$ & $8.006^{b}$ & $1.616^{\mathrm{c}}$ & $1.046^{\mathrm{c}}$ & $1.118^{\mathrm{c}}$ \\
\hline $\mathrm{Ni}$ & A & $0.094^{\mathrm{c}}$ & $0.064^{\mathrm{c}}$ & $8.43^{\mathrm{a}}$ & $7.73^{\mathrm{a}}$ & $1.91^{b}$ & $0.738^{b c}$ & $0.860^{b c}$ \\
\hline S & $\mathrm{Y}$ & $0.93^{\text {cd }}$ & $0.79^{\mathrm{d}}$ & $1.89^{a}$ & $1.42^{\mathrm{b}}$ & $1.04^{\mathrm{c}}$ & $1.35^{b}$ & $0.82^{d}$ \\
\hline S & A & $0.82^{b}$ & $1.00^{b}$ & $1.69^{\mathrm{a}}$ & $1.41^{\mathrm{ab}}$ & $1.02^{b}$ & $1.42^{\mathrm{a}}$ & $0.83^{b}$ \\
\hline
\end{tabular}

Statistical tests as in Table 4.

also of nickel when environmental levels of copper and nickel are high (Bagatto and Shorthouse 1991). Vegetation is contaminated by lead mainly through the retention of particulate matter (Thomas et al. 1984). It is thus evident that most of the copper and lead in plants have been accumulated from airborne deposition.

The increased nickel and cadmium concentrations in plants grown on plots and in pots at Harjavalta showed that these elements were easily accumulated by plants from airborne deposi- tion. Lettuce took up high concentrations of cadmium in PAP and TAM soil, a finding that is consistent with that of Gardiner et al. (1995). They reported that the mobility of cadmium into plants from soil appears to be greater than the mobility of zinc, copper and nickel.

The yields of and the element concentrations in plants determined from the second and third yields in 1985, 1986 and 1988 confirmed the results presented here. 


\section{AGRICULTURAL AND FOOD SCIENCE IN FINLAND}

Yläranta, T. Uptake of heavy metals by plants from airborne deposition and polluted soils

Table 7. Mean dry matter yield, g/plot (Y) or pot (A), S, and heavy metal concentrations ( $\mathrm{mg} / \mathrm{kg}$ of dry matter) of first yield of timothy at Jokioinen (JOKO) and (JOKN), Harjavalta (TAM, POH, PAP, TUP) and Kokemäki (SAT) in 1985 and 1986.

\begin{tabular}{|c|c|c|c|c|c|c|c|c|}
\hline \multicolumn{2}{|c|}{ Timothy } & JOKO & JOKN & TAM & $\mathrm{POH}$ & PAP & TUP & SAT \\
\hline \multicolumn{9}{|l|}{1985} \\
\hline Yield Y & $\mathrm{Y}$ & 1925 & 2339 & 2717 & 2076 & 2201 & 2316 & 2800 \\
\hline Yield $A$ & A & $18.9^{\mathrm{b}}$ & $19.8^{b}$ & $26.1^{\mathrm{a}}$ & $19.7^{b}$ & $25.3^{a}$ & $22.6^{\mathrm{ab}}$ & $25.9^{a}$ \\
\hline $\mathrm{Zn} \quad \mathrm{Y}$ & $\mathrm{Y}$ & $26^{b}$ & $25^{b}$ & $88^{a}$ & $88^{a}$ & $87^{a}$ & $28^{\mathrm{b}}$ & $24^{\mathrm{b}}$ \\
\hline $\mathrm{Zn}$ & A & $29^{b}$ & $37^{a}$ & $36^{\mathrm{a}}$ & $35^{\mathrm{ab}}$ & $38^{a}$ & $32^{\mathrm{ab}}$ & $36^{\mathrm{a}}$ \\
\hline $\mathrm{Cu}$ & $\mathrm{Y}$ & $4.6^{d}$ & $4.6^{d}$ & $28.7^{a}$ & $20.7^{b}$ & $16.5^{b}$ & $9.5^{c}$ & $7.6^{\text {cd }}$ \\
\hline $\mathrm{Cu}$ & A & $4.5^{c}$ & $6.3^{\mathrm{bc}}$ & $13.5^{\mathrm{a}}$ & $14.4^{\mathrm{a}}$ & $9.4^{b}$ & $6.2^{\mathrm{bc}}$ & $6.9^{b c}$ \\
\hline $\mathrm{Pb}$ & $\mathrm{Y}$ & $0.30^{\mathrm{c}}$ & $0.31^{\mathrm{c}}$ & $1.25^{\mathrm{a}}$ & $1.00^{\mathrm{b}}$ & $0.26^{\mathrm{c}}$ & $0.38^{\mathrm{c}}$ & $0.42^{\mathrm{c}}$ \\
\hline $\mathrm{Pb}$ & A & $0.24^{c}$ & $0.32^{\mathrm{c}}$ & $0.56^{b}$ & $0.97^{\mathrm{a}}$ & $0.18^{\mathrm{c}}$ & $0.25^{c}$ & $0.31^{\mathrm{c}}$ \\
\hline $\mathrm{Cd}$ & $\mathrm{Y}$ & $0.047^{b}$ & $0.049^{b}$ & $0.442^{\mathrm{a}}$ & $0.445^{\mathrm{a}}$ & $0.076^{b}$ & $0.105^{b}$ & $0.056^{b}$ \\
\hline $\mathrm{Cd}$ & A & $0.036^{e}$ & $0.056^{c}$ & $0.062^{b}$ & $0.150^{\mathrm{a}}$ & $0.041^{\mathrm{d}}$ & $0.041^{\mathrm{d}}$ & $0.029^{f}$ \\
\hline $\mathrm{Ni}$ & $\mathrm{Y}$ & $0.78^{d}$ & $1.08^{d}$ & $13.46^{\mathrm{b}}$ & $23.98^{\mathrm{a}}$ & $6.28^{\mathrm{c}}$ & $1.88^{\mathrm{d}}$ & $1.60^{\mathrm{d}}$ \\
\hline $\mathrm{Ni}$ & A & $0.48^{d}$ & $0.76^{\text {cd }}$ & $1.40^{\mathrm{b}}$ & $3.80^{\mathrm{a}}$ & $1.25^{\mathrm{bc}}$ & $0.50^{\mathrm{d}}$ & $0.56^{d}$ \\
\hline S & $\mathrm{Y}$ & $1.50^{e}$ & $1.98^{\mathrm{d}}$ & $2.72^{\mathrm{ab}}$ & $2.44^{\mathrm{bc}}$ & $2.87^{\mathrm{a}}$ & $2.32^{\mathrm{c}}$ & $2.18^{\mathrm{cd}}$ \\
\hline $\mathrm{S}$ & A & $1.38^{\mathrm{c}}$ & $1.79^{b}$ & $1.85^{b}$ & $1.91^{\mathrm{b}}$ & $2.26^{\mathrm{a}}$ & $1.83^{b}$ & $1.80^{\mathrm{b}}$ \\
\hline \multicolumn{9}{|l|}{1986} \\
\hline Yield Y & $\mathrm{Y}$ & 3783 & 4405 & 3536 & 4236 & 2952 & 4231 & 4091 \\
\hline Yield $A$ & A & $28.2^{\mathrm{a}}$ & $23.5^{\mathrm{a}}$ & $22.9^{\mathrm{a}}$ & $32.3^{\mathrm{a}}$ & $27.8^{\mathrm{a}}$ & $24.5^{\mathrm{a}}$ & $28.7^{a}$ \\
\hline $\mathrm{Zn} \quad \mathrm{Y}$ & $\mathrm{Y}$ & $25^{\mathrm{c}}$ & $21^{\mathrm{c}}$ & $93^{a}$ & $72^{b}$ & $62^{b}$ & $33^{\mathrm{c}}$ & $22^{\mathrm{c}}$ \\
\hline $\mathrm{Zn}$ & A & $25^{\mathrm{b}}$ & $26^{b}$ & $40^{\mathrm{a}}$ & $29^{b}$ & $29^{b}$ & $29^{b}$ & $23^{b}$ \\
\hline $\mathrm{Cu}$ & $\mathrm{Y}$ & $4.0^{\mathrm{cd}}$ & $3.0^{\mathrm{d}}$ & $29.8^{a}$ & $19.5^{b}$ & $9.3^{\mathrm{c}}$ & $8.9^{c}$ & $5.5^{\text {cd }}$ \\
\hline $\mathrm{Cu}$ & A & $3.6^{\mathrm{c}}$ & $4.3^{c}$ & $28.1^{\mathrm{a}}$ & $13.4^{b}$ & $6.2^{\mathrm{c}}$ & $6.5^{c}$ & $4.1^{\mathrm{c}}$ \\
\hline $\mathrm{Pb}$ & $\mathrm{Y}$ & $0.26^{\mathrm{bc}}$ & $0.15^{c}$ & $1.36^{\mathrm{a}}$ & $1.14^{\mathrm{a}}$ & $0.57^{b}$ & $0.29^{b c}$ & $0.20^{\mathrm{c}}$ \\
\hline $\mathrm{Pb}$ & A & $0.24^{d}$ & $0.23^{d}$ & $1.68^{\mathrm{a}}$ & $0.97^{\mathrm{b}}$ & $0.64^{\mathrm{c}}$ & $0.26^{d}$ & $0.20^{d}$ \\
\hline $\mathrm{Cd}$ & $\mathrm{Y}$ & $0.030^{d}$ & $0.035^{\mathrm{c}}$ & $0.251^{\mathrm{a}}$ & $0.176^{b}$ & $0.031^{\mathrm{d}}$ & $0.029^{\mathrm{de}}$ & $0.028^{\circ}$ \\
\hline $\mathrm{Cd}$ & A & $0.019^{f}$ & $0.016^{f}$ & $0.246^{\mathrm{a}}$ & $0.078^{b}$ & $0.034^{c}$ & $0.024^{d}$ & $0.024^{d}$ \\
\hline $\mathrm{Ni}$ & $\mathrm{Y}$ & $0.47^{\mathrm{c}}$ & $0.57^{\mathrm{c}}$ & $20.72^{b}$ & $25.41^{\mathrm{a}}$ & $2.38^{\mathrm{c}}$ & $1.47^{\mathrm{c}}$ & $1.04^{c}$ \\
\hline $\mathrm{Ni}$ & A & $0.12^{\mathrm{c}}$ & $0.28^{\mathrm{c}}$ & $14.57^{\mathrm{a}}$ & $6.34^{b}$ & $1.18^{\mathrm{c}}$ & $0.65^{c}$ & $0.30^{\mathrm{c}}$ \\
\hline $\mathrm{S}$ & $\mathrm{Y}$ & $1.49^{\mathrm{d}}$ & $1.64^{\text {cd }}$ & $2.09^{\mathrm{abc}}$ & $2.39^{\mathrm{a}}$ & $1.79^{\text {bad }}$ & $2.21^{\mathrm{ab}}$ & $1.62^{\mathrm{d}}$ \\
\hline S & A & $1.73^{\mathrm{cd}}$ & $1.86^{\text {bed }}$ & $2.68^{\mathrm{a}}$ & $2.12^{\mathrm{bc}}$ & $1.97^{\text {bed }}$ & $2.23^{\mathrm{ab}}$ & $1.59^{\mathrm{d}}$ \\
\hline
\end{tabular}

Statistical tests as in Table 4.

\section{Pot experiment}

The addition of $200 \mathrm{mg}$ of $\mathrm{Cu}$ and $1000 \mathrm{mg}$ of $\mathrm{Ni}$ per pot increased the amounts of soluble salts in pot soils (Table 10). These increments were very clear with the largest additions of copper or nickel. The bulk of the copper and nickel added to the soils was in HAAC-EDTA-extractable form at the end of the experiment.

The largest addition of copper and nickel $(1000 \mathrm{mg} / \mathrm{pot})$ killed the oats in EPO soils. Liming, which raised the soil $\mathrm{pH}\left(\mathrm{CaCl}_{2}\right)$ by $1.5-1.7$
$\mathrm{pH}$ unit, saved the plants, and yields increased almost to the control level. Liming lowered the HAAC-EDTA-extractable copper and nickel concentrations in the soil and the concentrations of these elements in the oats shoots. However, liming had a minor effect on the copper concentrations in oats shoots because these concentrations were largely independent of the copper added to the soils. Likewise in the pot experiment carried out by Gorlach and Gambus (1992) liming of acidic soil combined with the addition 
Vol. 5 (1996): 431-447.

Table 8 . Mean dry matter yield, g/plot $(\mathrm{Y})$ or pot (A), S, and heavy metal concentrations (mg/kg of dry matter) of first yield of rye grass at Jokioinen (JOKO) and (JOKN), Harjavalta (TAM, POH, PAP, TUP) and Kokemäki (SAT) in 1985 and 1986.

\begin{tabular}{|c|c|c|c|c|c|c|c|c|}
\hline & & JOKO & JOKN & TAM & $\mathrm{POH}$ & PAP & TUP & SAT \\
\hline \multicolumn{9}{|l|}{1985} \\
\hline Yield & $\mathrm{Y}$ & 2578 & 2890 & 2732 & 2939 & 2985 & 2572 & 2641 \\
\hline Yield & A & $34.9^{\mathrm{a}}$ & $26.6^{b c}$ & $28.1^{b c}$ & $32.7 \mathrm{ab}$ & $17.0^{\mathrm{d}}$ & $25.2^{\mathrm{c}}$ & $27.7^{b c}$ \\
\hline $\mathrm{Zn}$ & $\mathrm{Y}$ & $20^{c}$ & $19^{\mathrm{c}}$ & $49^{b}$ & $68^{a}$ & $73^{a}$ & $21^{c}$ & $21^{\mathrm{c}}$ \\
\hline $\mathrm{Zn}$ & A & $21^{\mathrm{c}}$ & $22^{\mathrm{c}}$ & $22^{\mathrm{c}}$ & $35^{a}$ & $28^{\mathrm{b}}$ & $21^{c}$ & $21^{\mathrm{c}}$ \\
\hline $\mathrm{Cu}$ & $\mathrm{Y}$ & $4.3^{c}$ & $4.9^{\mathrm{c}}$ & $38.1^{a}$ & $37.2^{a}$ & $30.8^{a}$ & $13.7^{\mathrm{b}}$ & $10.8^{\mathrm{bc}}$ \\
\hline $\mathrm{Cu}$ & A & $4.0^{e}$ & $6.2^{\mathrm{de}}$ & $22.5^{\mathrm{b}}$ & $31.6^{a}$ & $13.3^{c}$ & $8.3^{d}$ & $6.8^{\mathrm{de}}$ \\
\hline $\mathrm{Pb}$ & $\mathrm{Y}$ & $0.66^{\mathrm{bc}}$ & $0.26^{\mathrm{c}}$ & $1.18^{\mathrm{b}}$ & $3.25^{\mathrm{a}}$ & $0.49^{c}$ & $0.27^{\mathrm{c}}$ & $0.24^{c}$ \\
\hline $\mathrm{Pb}$ & A & $0.78^{b}$ & $0.20^{c}$ & $0.78^{b}$ & $3.21^{\mathrm{a}}$ & $0.38^{\mathrm{bc}}$ & $0.19^{\mathrm{c}}$ & $0.21^{c}$ \\
\hline $\mathrm{Cd}$ & $\mathrm{Y}$ & $0.06^{c}$ & $0.16^{b}$ & $0.37^{a}$ & $0.42^{\text {a }}$ & $0.15^{b}$ & $0.10^{\mathrm{bc}}$ & $0.109^{b c}$ \\
\hline $\mathrm{Cd}$ & A & $0.066^{e}$ & $0.069^{d}$ & $0.089^{b}$ & $0.101^{\text {a }}$ & $0.074^{c}$ & $0.056^{f}$ & $0.042^{g}$ \\
\hline $\mathrm{Ni}$ & $\mathrm{Y}$ & $0.9^{d}$ & $1.4^{\mathrm{d}}$ & $14.0^{b}$ & $23.0^{\mathrm{a}}$ & $6.1^{\mathrm{c}}$ & $1.60^{d}$ & $1.84^{d}$ \\
\hline $\mathrm{Ni}$ & A & $0.52^{c}$ & $0.86^{\mathrm{c}}$ & $1.90^{\mathrm{b}}$ & $4.37^{a}$ & $0.82^{\mathrm{c}}$ & $0.60^{\mathrm{c}}$ & $0.66^{c}$ \\
\hline $\mathrm{S}$ & $\mathrm{Y}$ & $1.61^{c}$ & $2.08^{b}$ & $3.90^{\mathrm{a}}$ & $3.51^{\mathrm{a}}$ & $3.52^{\mathrm{a}}$ & $2.26^{\mathrm{b}}$ & $2.52^{b}$ \\
\hline S & A & $1.81^{\mathrm{d}}$ & $2.29^{\mathrm{c}}$ & $2.79^{b}$ & $2.16^{\mathrm{cd}}$ & $3.73^{a}$ & $2.80^{b}$ & $2.49^{\mathrm{bc}}$ \\
\hline \multicolumn{9}{|l|}{1986} \\
\hline Yield & $\mathrm{Y}$ & 4445 & 3286 & 3168 & 3087 & 2655 & 2935 & 2383 \\
\hline Yield & A & $18.1^{\circ}$ & $25.0^{\mathrm{bc}}$ & $31.7^{b}$ & $43.2^{\mathrm{a}}$ & $29.0^{b}$ & $29.8^{b}$ & $28.9^{b}$ \\
\hline $\mathrm{Zn}$ & $\mathrm{Y}$ & $20^{d}$ & $23^{d}$ & $46^{b}$ & $41^{c}$ & $53^{a}$ & $21^{\mathrm{d}}$ & $22^{\mathrm{d}}$ \\
\hline $\mathrm{Zn}$ & A & $25^{\text {bed }}$ & $29^{\mathrm{ab}}$ & $28^{\mathrm{ab}}$ & $22^{\mathrm{d}}$ & $30^{a}$ & $23^{\mathrm{cd}}$ & $26^{\mathrm{abc}}$ \\
\hline $\mathrm{Cu}$ & $\mathrm{Y}$ & $4.5^{d}$ & $4.6^{d}$ & $45.9^{\mathrm{a}}$ & $25.3^{b}$ & $28.0^{b}$ & $12.3^{\mathrm{c}}$ & $14.9^{c}$ \\
\hline $\mathrm{Cu}$ & A & $5.5^{d}$ & $5.6^{d}$ & $30.0^{\mathrm{a}}$ & $21.6^{b}$ & $21.3^{b}$ & $9.6^{\text {cd }}$ & $13.2^{\mathrm{c}}$ \\
\hline $\mathrm{Pb}$ & $\mathrm{Y}$ & $0.38^{\text {ed }}$ & $0.24^{d}$ & $1.89^{\mathrm{a}}$ & $1.29^{\mathrm{b}}$ & $1.68^{\mathrm{a}}$ & $0.56^{\mathrm{c}}$ & $0.55^{c}$ \\
\hline $\mathrm{Pb}$ & A & $0.41^{\text {cd }}$ & $0.25^{d}$ & $1.39^{\mathrm{a}}$ & $1.20^{\mathrm{ab}}$ & $1.48^{\mathrm{a}}$ & $0.59^{\text {cd }}$ & $0.78^{b c}$ \\
\hline $\mathrm{Cd}$ & $\mathrm{Y}$ & $0.06^{c}$ & $0.20^{b}$ & $0.50^{a}$ & $0.46^{\mathrm{a}}$ & $0.19^{b}$ & $0.11^{c}$ & $0.243^{b}$ \\
\hline $\mathrm{Cd}$ & A & $0.053^{f}$ & $0.091^{e}$ & $0.209^{b}$ & $0.248^{a}$ & $0.163^{c}$ & $0.092^{e}$ & $0.133^{d}$ \\
\hline $\mathrm{Ni}$ & $\mathrm{Y}$ & $0.74^{e}$ & $0.88^{e}$ & $33.30^{b}$ & $38.21^{\text {a }}$ & $9.35^{c}$ & $3.09^{d}$ & $4.62^{d}$ \\
\hline $\mathrm{Ni}$ & A & $0.37^{e}$ & $0.32^{e}$ & $15.09^{a}$ & $10.42^{b}$ & $5.81^{\mathrm{c}}$ & $1.59^{\mathrm{de}}$ & $3.37^{\mathrm{d}}$ \\
\hline S & $\mathrm{Y}$ & $1.46^{d}$ & $2.03^{\mathrm{cd}}$ & $3.92^{\mathrm{a}}$ & $2.67^{b c}$ & $3.00^{b}$ & $2.93^{b}$ & $1.86^{b}$ \\
\hline S & A & $1.31^{\mathrm{d}}$ & $1.32^{\mathrm{d}}$ & $2.53^{\mathrm{a}}$ & $1.56^{\mathrm{c}}$ & $1.65^{c}$ & $2.13^{b}$ & $1.22^{\mathrm{d}}$ \\
\hline
\end{tabular}

Statistical tests as in Table 4.

of peat and phosphatic fertilizer diminished the phytoavailability of nickel, thus reducing its uptake by oats.

In copper-polluted PAP soil, copper additions retarded the growth of oats, and the addition of $1000 \mathrm{mg}$ of $\mathrm{Cu}$ per pot almost killed the oats in PAP and TAM soil. When the yields of oats shoots were very small the copper concentrations in the shoots had increased. In TAM soil even the smallest copper addition, $40 \mathrm{mg} / \mathrm{pot}$, decreased oats yield, implying that in TAM soil the copper concentration is already so high that it can be phytotoxic for plants.

Additions of nickel to PAP and TAM soils retarded the growth of oats very clearly. The addition of as little as $200 \mathrm{mg}$ of Ni per pot impeded the growth of oats, and the addition of $1000 \mathrm{mg} /$ pot killed the oats plants in both soils. As in EPO soil, the copper concentrations in plants were low but nickel concentrations high in TAM and PAP soils.

Risk assessment values collected by Finne- 


\section{AGRICULTURAL AND FOOD SCIENCE IN FINLAND}

Yläranta, T. Uptake of heavy metals by plants from airborne deposition and polluted soils

Table 9. Mean dry matter yield ( $\mathrm{g} /$ plot or pot) and heavy metal concentrations $(\mathrm{mg} / \mathrm{kg}$ of dry matter) of spring wheat grain and straw, rye grass and lettuce at Jokioinen (JOKA) and at Harjavalta (TAMI, JOHA) in 1988 .

\begin{tabular}{|c|c|c|c|c|c|c|}
\hline & \multicolumn{3}{|c|}{ Plots } & \multicolumn{3}{|c|}{ Pots } \\
\hline & JOKA & TAMI & JOHA & JOKA & TAMI & JOHA \\
\hline \multicolumn{7}{|c|}{$\begin{array}{l}\text { Wheat, } \\
\text { grain }\end{array}$} \\
\hline Yield & 2110 & 2530 & 2424 & $13.4^{\mathrm{b}}$ & $24.2^{\mathrm{a}}$ & $21.6^{\mathrm{a}}$ \\
\hline $\mathrm{Zn}$ & $34^{c}$ & $49^{\mathrm{a}}$ & $44^{b}$ & $76^{a}$ & $50^{\mathrm{c}}$ & $63^{b}$ \\
\hline $\mathrm{Cu}$ & $4.3^{\mathrm{c}}$ & $9.3^{\mathrm{a}}$ & $8.0^{b}$ & $4.7^{b}$ & $6.7^{\mathrm{a}}$ & $6.8^{\mathrm{a}}$ \\
\hline $\mathrm{Pb}$ & $0.03^{\mathrm{a}}$ & $0.07^{a}$ & $0.09^{a}$ & $0.04^{\mathrm{a}}$ & $0.05^{\mathrm{a}}$ & $0.08^{a}$ \\
\hline $\mathrm{Cd}$ & $0.03^{\mathrm{c}}$ & $0.12^{a}$ & $0.07^{b}$ & $0.04^{b}$ & $0.03^{c}$ & $0.05^{\mathrm{a}}$ \\
\hline $\mathrm{Ni}$ & $0.1^{\mathrm{c}}$ & $14.2^{\mathrm{a}}$ & $7.2^{b}$ & $0.06^{b}$ & $6.8^{\mathrm{a}}$ & $7.0^{\mathrm{a}}$ \\
\hline \multicolumn{7}{|c|}{$\begin{array}{l}\text { Wheat, } \\
\text { straw }\end{array}$} \\
\hline Yield & 2120 & 4290 & 5016 & $26.4^{b}$ & $36.2^{\mathrm{a}}$ & $44.4^{\mathrm{a}}$ \\
\hline $\mathrm{Zn}$ & $7.5^{b}$ & $32.5^{\mathrm{a}}$ & $25^{a}$ & $53^{\mathrm{a}}$ & $34^{b}$ & $29^{b}$ \\
\hline $\mathrm{Cu}$ & $2.3^{\mathrm{c}}$ & $47.3^{a}$ & $18.7^{b}$ & $3.7^{b}$ & $23.6^{\mathrm{a}}$ & $9.3^{\mathrm{a}}$ \\
\hline $\mathrm{Pb}$ & $0.34^{c}$ & $2.07^{a}$ & $1.21^{\mathrm{b}}$ & $0.18^{b}$ & $0.79^{\mathrm{a}}$ & 0.67 \\
\hline $\mathrm{Cd}$ & $0.04^{\mathrm{c}}$ & $0.51^{\mathrm{a}}$ & $0.19^{a}$ & $0.12^{a}$ & $0.11^{b}$ & $0.08^{c}$ \\
\hline $\mathrm{Ni}$ & $0.1^{\mathrm{c}}$ & $19.4^{\mathrm{a}}$ & $5.3^{b}$ & $0.1^{\mathrm{c}}$ & $8.0^{\mathrm{a}}$ & $2.4^{b}$ \\
\hline \multicolumn{7}{|l|}{$\begin{array}{l}\text { Rye } \\
\text { grass }\end{array}$} \\
\hline Yield & 1780 & 1990 & 2410 & $49.3^{\mathrm{a}}$ & $44.8^{b}$ & $33.8^{b}$ \\
\hline $\mathrm{Zn}$ & $21^{b}$ & $58^{\circ}$ & $51^{a}$ & $38^{a}$ & $37^{a}$ & $36^{a}$ \\
\hline $\mathrm{Cu}$ & $6.4^{\mathrm{c}}$ & $54^{a}$ & $34^{b}$ & $6.3^{\mathrm{c}}$ & $37.3^{\mathrm{a}}$ & $21.9^{b}$ \\
\hline $\mathrm{Pb}$ & $0.22^{\mathrm{c}}$ & $1.71^{\mathrm{a}}$ & $1.22^{b}$ & $0.29^{c}$ & $1.38^{\mathrm{a}}$ & $0.95^{b}$ \\
\hline $\mathrm{Cd}$ & $0.11^{\mathrm{c}}$ & $0.35^{a}$ & $0.24^{b}$ & $0.117^{b}$ & $0.120^{\mathrm{a}}$ & $0.092^{\mathrm{c}}$ \\
\hline $\mathrm{Ni}$ & $0.9^{\mathrm{c}}$ & $40.7^{a}$ & $23.0^{b}$ & $0.7^{c}$ & $19.2^{\mathrm{a}}$ & $6.8^{b}$ \\
\hline \multicolumn{7}{|c|}{ Lettuce } \\
\hline Yield & 840 & 696 & 1640 & $22.5^{b}$ & $25.9^{\mathrm{ab}}$ & $36.1^{\mathrm{a}}$ \\
\hline $\mathrm{Zn}$ & $31^{\mathrm{c}}$ & $154^{\mathrm{a}}$ & $73^{b}$ & $47^{b}$ & $50^{b}$ & $61^{\text {a }}$ \\
\hline $\mathrm{Cu}$ & $6.6^{b}$ & $20.4^{\mathrm{a}}$ & $19.3^{a}$ & $5.6^{b}$ & $15.2^{\mathrm{a}}$ & $11.8^{\mathrm{a}}$ \\
\hline $\mathrm{Pb}$ & $0.67^{\mathrm{a}}$ & $0.70^{\mathrm{a}}$ & $0.85^{a}$ & $0.25^{\mathrm{a}}$ & $0.48^{\mathrm{a}}$ & $0.49^{\mathrm{a}}$ \\
\hline $\mathrm{Cd}$ & $0.40^{\mathrm{b}}$ & $2.26^{\mathrm{a}}$ & $1.14^{\mathrm{ab}}$ & $0.28^{a}$ & $0.28^{a}$ & $0.32^{\mathrm{a}}$ \\
\hline $\mathrm{Ni}$ & $0.8^{\mathrm{c}}$ & $36.2^{a}$ & $12.1^{b}$ & $0.5^{\mathrm{c}}$ & $7.8^{\mathrm{a}}$ & $4.9^{b}$ \\
\hline
\end{tabular}

Statistical tests as in Table 4.

cy (1987) from polluted soils show that such soils can pose a risk to humans, animals, plants and water. According to a Dutch assessment based on the demand that soil retain its 'multifunctionality', soil is polluted and clean up necessary when copper and nickel concentrations exceed $500 \mathrm{mg} / \mathrm{kg}$ of soil (Moen et al. 1985). The present study showed that this limit is too high for both of these elements in Finland. In acidic soil
(EPO), a nickel concentration of less than $20 \mathrm{mg} /$ $\mathrm{kg}$ of soil and a copper concentration of less than $100 \mathrm{mg} / \mathrm{kg}$ of soil clearly reduced the dry matter yields of oats shoots. In polluted PAP and TAM soils these risk values were somewhat higher but then $\mathrm{pH}\left(\mathrm{CaCl}_{2}\right)$ was higher than in EPO soil. From the investigations of the effect of particular heavy metals on plants it follows, however, that their tolerance to an increased heavy metal 
Vol. 5 (1996): 431-447.

Table 10. Mean dry matter yields (g/plot or pot), copper and nickel concentrations (mg/kg of dry matter) and uptake (mg/ pot) of oats shoots in pot experiment in EPO, PAP and TAM soils in 1990. No Li. $=$ No liming. EC = electrical conductivity $\left(10^{-4} \times \mathrm{S} / \mathrm{cm}\right), \mathrm{pH}=\mathrm{CaCl}_{2}$, Extract. $=$ HAAC-EDTA-extractable concentrations of copper and nickel.

\begin{tabular}{|c|c|c|c|c|c|c|c|c|c|}
\hline & \multirow[b]{2}{*}{$\mathrm{EC}$} & \multirow[b]{2}{*}{$\mathrm{pH}$} & \multicolumn{2}{|c|}{$\begin{array}{l}\text { Extract. } \\
\text { mg/pot }\end{array}$} & \multirow{2}{*}{$\begin{array}{l}\text { g/pot } \\
\text { Yield }\end{array}$} & \multicolumn{2}{|c|}{$\begin{array}{c}\text { Concentr. } \\
\mathrm{mg} / \mathrm{kg}\end{array}$} & \multicolumn{2}{|c|}{$\begin{array}{l}\text { Uptake } \\
\text { mg/pot }\end{array}$} \\
\hline & & & $\mathrm{Cu}$ & $\mathrm{Ni}$ & & $\mathrm{Cu}$ & $\mathrm{Ni}$ & $\mathrm{Cu}$ & $\mathrm{Ni}$ \\
\hline \multicolumn{10}{|l|}{ ЕРО Cи } \\
\hline \multicolumn{10}{|l|}{ No Li. } \\
\hline Control & $5^{c}$ & $4.5^{a}$ & $13^{d}$ & $10^{b}$ & $7.7^{a}$ & $6.5^{b}$ & $14.1^{b}$ & 0.05 & 0.11 \\
\hline $\mathrm{Cu} \quad 40$ & $5^{c}$ & $4.5^{a}$ & $39^{c}$ & $10^{b}$ & $8.8^{a}$ & $8.6^{b}$ & $14.6^{b}$ & 0.08 & 0.13 \\
\hline 200 & $9^{b}$ & $4.4^{a b}$ & $165^{b}$ & $12^{a}$ & $5.1^{\mathrm{b}}$ & $17.1^{\mathrm{a}}$ & $27.6^{a}$ & 0.09 & 0.14 \\
\hline 1000 & $16^{a}$ & $4.2^{b}$ & $845^{a}$ & $13^{a}$ & $\left.-^{*}\right)$ & - & - & - & - \\
\hline \multicolumn{10}{|l|}{ Liming } \\
\hline Control & $5^{b}$ & $4.5^{b}$ & $13^{c}$ & $10^{\mathrm{a}}$ & $7.7^{b}$ & $6.5^{\mathrm{bc}}$ & $14.1^{\mathrm{a}}$ & 0.05 & 0.11 \\
\hline Con./ Li & $7^{b}$ & $6.1^{\mathrm{a}}$ & $15^{c}$ & $7^{b}$ & $10.0^{\mathrm{a}}$ & $4.9^{c}$ & $2.3^{b}$ & 0.05 & 0.02 \\
\hline $\mathrm{Cu} \quad 40$ & $7^{b}$ & $6.2^{\mathrm{a}}$ & $56^{c}$ & $7^{b}$ & $8.6^{\mathrm{ab}}$ & $7.5^{\mathrm{abc}}$ & $2.4^{b}$ & 0.06 & 0.02 \\
\hline 200 & $8^{b}$ & $6.1^{\mathrm{a}}$ & $148^{b}$ & $6^{b c}$ & $9.8^{\mathrm{a}}$ & $8.1^{a b}$ & $2.8^{\mathrm{b}}$ & 0.08 & 0.03 \\
\hline 1000 & $13^{a}$ & $6.0^{a}$ & $670^{a}$ & $5^{c}$ & $5.7^{b}$ & $9.4^{\mathrm{a}}$ & $3.7^{b}$ & 0.05 & 0.02 \\
\hline \multicolumn{10}{|l|}{ EPO Ni } \\
\hline \multicolumn{10}{|l|}{ No $\mathrm{Li}$. } \\
\hline Control & $5^{\mathrm{c}}$ & $4.5^{\mathrm{a}}$ & $13^{\mathrm{ab}}$ & $10^{c}$ & $7.7^{\mathrm{a}}$ & $6.5^{a}$ & $14.1^{b}$ & 0.05 & 0.11 \\
\hline $\mathrm{Ni} \quad 40$ & $6^{c}$ & $4.5^{a}$ & $13^{a}$ & $49^{c}$ & $6.8^{b}$ & $5.1^{\mathrm{b}}$ & $70.6^{b}$ & 0.03 & 0.48 \\
\hline 200 & $10^{\mathrm{b}}$ & $4.3^{b}$ & $12^{\mathrm{ab}}$ & $210^{b}$ & $0.4^{\mathrm{c}}$ & $1.8^{\mathrm{c}}$ & $395.4^{a}$ & 0.00 & 0.15 \\
\hline 1000 & $15^{a}$ & $4.4^{b}$ & $11^{b}$ & $986^{a}$ & - & - & - & - & - \\
\hline \multicolumn{10}{|l|}{ Liming } \\
\hline Control & $5^{b}$ & $4.5^{b}$ & $13^{b}$ & $10^{c}$ & 7.7 & $6.5^{a}$ & $14.1^{\mathrm{c}}$ & 0.05 & 0.11 \\
\hline Con./ Li & $7^{b}$ & $6.1^{\mathrm{a}}$ & $15^{a}$ & $7^{c}$ & 10.0 & $4.9^{b}$ & $2.3^{\mathrm{d}}$ & 0.05 & 0.02 \\
\hline $\mathrm{Ni} \quad 40$ & $7^{b}$ & $6.1^{\mathrm{a}}$ & $16^{a}$ & $30^{c}$ & 9.0 & $1.4^{\mathrm{c}}$ & $6.0^{\text {ed }}$ & 0.01 & 0.05 \\
\hline 200 & $7^{b}$ & $6.2^{\mathrm{a}}$ & $16^{a}$ & $92^{b}$ & 9.9 & $4.7^{b}$ & $26.5^{b}$ & 0.05 & 0.26 \\
\hline 1000 & $14^{a}$ & $6.0^{a}$ & $14^{\mathrm{ab}}$ & $444^{a}$ & 7.0 & $3.6^{b}$ & $71.1^{a}$ & 0.02 & 0.48 \\
\hline \multicolumn{10}{|l|}{$P A P C u$} \\
\hline Control & $5^{b}$ & 5.1 & $73^{d}$ & 8 & $11.9^{\mathrm{a}}$ & $10.7^{\mathrm{c}}$ & $10.9^{c}$ & 0.13 & 0.13 \\
\hline $\mathrm{Cu} \quad 40$ & $5^{b}$ & 5.1 & $107^{e}$ & 8 & $11.1^{\mathrm{a}}$ & $11.6^{c}$ & $11.9^{c}$ & 0.13 & 0.13 \\
\hline 200 & $7^{b}$ & 5.0 & $238^{\mathrm{b}}$ & 8 & $10.9^{\mathrm{a}}$ & $14.1^{b}$ & $16.3^{b}$ & 0.15 & 0.19 \\
\hline 1000 & $16^{a}$ & 4.9 & $930^{\circ}$ & 9 & $0.5^{b}$ & $18.7^{a}$ & $20.7^{a}$ & 0.01 & 0.01 \\
\hline \multicolumn{10}{|l|}{ PAP Ni } \\
\hline Control & $5^{c}$ & $5.1^{\mathrm{a}}$ & 73 & $8^{d}$ & $11.9^{\mathrm{a}}$ & $10.7^{a}$ & $10.9^{c}$ & 0.13 & 0.13 \\
\hline $\mathrm{Ni} \quad 40$ & $5^{c}$ & $5.1^{\mathrm{a}}$ & 73 & $41^{c}$ & $11.5^{\mathrm{a}}$ & $9.9^{a}$ & $45.5^{b}$ & 0.11 & 0.52 \\
\hline 200 & $12^{b}$ & $4.9^{b}$ & 72 & $181^{b}$ & $4.3^{b}$ & $7.0^{b}$ & $175.6^{\mathrm{a}}$ & 0.03 & 0.75 \\
\hline 1000 & $17^{a}$ & $5.0^{\mathrm{ab}}$ & 75 & 925 a & - & - & - & - & - \\
\hline \multicolumn{10}{|l|}{ TAM Cu } \\
\hline Control & $5^{c}$ & $5.6^{\mathrm{a}}$ & $325^{c}$ & 36 & $12.7^{a}$ & $13.7^{b}$ & $40.6^{b}$ & 0.17 & 0.52 \\
\hline $\mathrm{Cu} \quad 40$ & $5^{c}$ & $5.6^{\mathrm{a}}$ & $359^{c}$ & 34 & $10.4^{b}$ & $14.7^{b}$ & $41.2^{b}$ & 0.15 & 0.43 \\
\hline 200 & $9^{b}$ & $5.4^{\mathrm{ab}}$ & $476^{b}$ & 36 & $7.1^{\mathrm{c}}$ & $13.0^{\mathrm{b}}$ & $47.8^{b}$ & 0.09 & 0.34 \\
\hline 1000 & $16^{a}$ & $5.3^{b}$ & $1136^{a}$ & 37 & $0.4^{d}$ & $29.9^{\mathrm{a}}$ & $77.8^{\mathrm{a}}$ & 0.01 & 0.03 \\
\hline \multicolumn{10}{|l|}{ TAM Ni } \\
\hline Control & $5^{b}$ & 5.6 & 325 & $36^{c}$ & $12.7^{\mathrm{a}}$ & 13.7 & $40.6^{b}$ & 0.17 & 0.52 \\
\hline $\mathrm{Ni} \quad 40$ & $6^{b}$ & 5.5 & 316 & $67^{c}$ & $11.7^{\mathrm{ab}}$ & 12.8 & $65.8^{\mathrm{ab}}$ & 0.15 & 0.77 \\
\hline 200 & $9^{b}$ & 5.4 & 312 & $176^{b}$ & $5.5^{b}$ & 11.6 & $150.3^{a}$ & 0.07 & 0.65 \\
\hline 1000 & $15^{a}$ & 5.5 & 311 & $943^{\text {a }}$ & - & - & - & - & - \\
\hline
\end{tabular}

Means not marked with a common letter differ from each other at the $1 \%$ significance level (Tukey's HSD, Honestly Significant Difference test). ${ }^{*}$ ) oats dead 


\section{AGRICULTURAL AND FOOD SCIENCE IN FINLAND}

Yläranta, T. Uptake of heavy metals by plants from airborne deposition and polluted soils

content depends on the plant species, and is different for different metals (e.g. Gorlach and Gambuś 1992).

The copper and nickel uptake by oats shoots was very small (Table 10).

\section{Conclusions}

Concentrations of zinc, copper, lead, cadmium and nickel varied between different plant species and also between experimental years. Differences in sulphur concentrations between plants were small.
The lead and copper concentrations of wheat grain were low, even at polluted sites. Especially nickel but also cadmium and copper were easily taken up by plants from soil and also accumulated from airborne deposition. In acidic soil, nickel and copper concentrations lower than 20 $\mathrm{mg} / \mathrm{kg}$ and $100 \mathrm{mg} / \mathrm{kg}$ of soil, respectively, decreased the dry matter yields of oats shoots. Liming clearly lowered copper and nickel phytotoxity.

In the pot experiment, the smallest addition of copper into TAM soil, $20 \mathrm{mg} / \mathrm{kg}$ of soil, decreased the yield of oats shoots. Thus, in the most highly polluted acidic soils at Harjavalta, the copper concentration is so high that it may decrease the yield of plants.

\section{References}

Andersson, A. \& Gustafson, A. 1988. Deposition av spårelement med nederbörden. Swedish University of Agricultural Sciences. Ekohydrologi 26: 5-12.

Ansorena, J., Marino, N. \& Legorburu, I. 1995. Agricultural use of polluted soil near an old lead-zinc mine in Oiartzun (Basque Country, Spain). Environmental Technology 16: 213-222.

Bagatto, G. \& Shorthouse, J.D. 1991. Accumulation of copper and nickel in plant tissues and an insect gall of lowbush blueberry, Vaccinium angustifolium, near an ore smelter at Sudbury, Ontario, Canada. Canadian Journal of Botany 69: 1483-1490.

Gardiner, D.T., Miller, R.W., Badamchian, B., Azzari, A.S. \& Sisson, D.R. 1995. Effects of repeated sewage sludge applications on plant accumulation of heavy metals. Agriculture, Ecosystems and Environment 55: 1-6.

Gorlach, E. \& Gambus, F. 1992. A comparison of sensitivity to the toxic action of heavy metals in various plant species. Polish Journal of Soil Science 25/2: 207-213.

Erviö, R., Mäkelä-Kurtto, R. \& Sippola, J. 1990. Chemical characteristics of Finnish agricultural soils in 1974 and 1987. In: Kauppi, P. et al. (eds.). Acidification in Finland. Springer-Verlag, Berlin. p. 214-234.

Finnecy, E.E. 1986. Impacts on soil related to industrial activities: Part II - Incidental and accidental soil pollution. In: Barth, H. \& L'Hermite, P. (eds.). Scientific basis for soil protection in the Europian Community. Proceedings of a symposium held in Berlin 6-8 October 1986. Elsevier Applied Science, London. p. 259-280.

Fotyma, M. \& Terelak, H. 1994. Environmental challenges in Polish agriculture covering a main area of the Baltic Sea Basin. Marine Pollution Bulletin 29: 455-463.

Hertz, J. 1991. Bioindicators for monitoring heavy met- als in the environment. In: Merian, E. (ed.) Metals and their compounds in the environment. $\mathrm{VCH}$ Verlagsgesellschaft mbH, Weinheim. p. 221-231.

Jensen, R.A. \& Laxen, D.P.H. 1987. The effect of the phase-down of lead in petrol on levels of lead in air. The Science of Total Environment 59: 1-8.

Mäkelä-Kurtto, R., Erviö, R. \& Sippola, J. 1993. Macro- and microelement concentrations of Finnish timothy in 1974 and 1987. Agricultural Science in Finland 2: 337344.

Mäntylahti, V. \& Yläranta, T. 1980. The estimation of soil lime requirement in soil testing. Annales Agriculturae Fenniae 19: 92-99.

Moen, J.E.T., Cornet, J.P. \& Evers, C.W.A. 1985. Soil protection and remedial actions: Criteria for decision making and standardisation of requirements. Proceedings 1st International TNO Conference on Contaminated soil, Utrecht, Netherlands, November 1985. Martinus Nijhoff, Dordrecht. p. 441-448.

Provincial Government of Turku \& Pori. 1987. Outokumpu Oy:n Harjavallan tehtaiden ilmansuojeluilmoitus. DNo 304336685 Ys Out (1145/B). Turku 29.10.1987.

Rühling, Á., Rasmussen, L., Pilegaard, K., Mäkinen, A. \& Steinnes, E. 1987. Survey of atmospheric heavy metal deposition in the nordic countries in 1985. NORD 1987: 21, $44 \mathrm{p}$.

-, Brumelius, G., Goltsova, N., Kvietkus, K., Kubin, E., Liiv, S., Magnusson, S., Mäkinen, A., Pilegaard, K., Rasmussen, L., Sander, E. \& Steinnes, E. 1992. Atmospheric heavy metal deposition in Northern Europe 1990. Nord 1992: 12, $41 \mathrm{p}$.

Thomas, W., Rühling, Ȧ. \& Simon, H. 1984. Accumulation of airborne pollutants (PAH, chlorinated hydrocar- 
Vol. 5 (1996): 431-447.

bons, heavy metals) in various plant species and humus. Environmental Pollution (Series A) 36: 295-310.

Yläranta, T. 1995. Effect of road traffic on heavy metal concentrations of plants. Agricultural Science in Finland 4: 35-48.

\title{
SELOSTUS
}

\section{Kasvien raskasmetallien otto ilmasta ja saastuneesta maasta}

\author{
Toivo Yläranta \\ Maatalouden tutkimuskeskus
}

Sinkin, kuparin, lyijyn, kadmiumin ja nikkelin kertymistä lehtisalaattiin, vehnän jyviin ja olkiin, timoteihin ja italianraiheinään tutkittiin vuonna 1985 , 1986 ja 1988 Harjavallassa ja sen ympäristössä sekä vertailupaikkakunnalla Jokioisissa. Harjavallassa toimivat Outokumpu Oy:n Harjavallan tehtaat ovat vuodesta 1945 lähtien levittäneet ympäristöönsä raskasmetalleja, erikoisesti kuparia ja nikkeliä. Keskeisin Outokumpu Oy:n Harjavallan tehtaista on ollut kupari- ja nikkelisulatto, joka on lajissaan Suomen ainoa. Harjavallassa on toiminut eräitä muitakin raskasmetallien, erikoisesti lyijyn, päästölähteitä. Tutkimuksessa selvitettiin raskasmetallien kertymistä kasveihin ilmasta ja saastuneesta maasta. Koepaikat sijaitsivat eri etäisyydellä ja eri suunnissa Outokumpu Oy:n tehtaista. Koepaikkojen valinnalla pyrittiin selvittämään raskasmetallien kulkeutumisetäisyyden ja -suunnan vaikutusta viljelykasvien raskasmetallipitoisuuteen.

Jokioisissa vuonna 1990 läpiviedyssä astiakokeessa tutkittiin, mikä viljelymaan kupari- ja nikkelipitoisuus pienentää viljelykasvin satoa. Kahteen harjavaltalaiseen kuparilla ja nikkelillä saastuneeseen hienohietamaahan lisättiin 40, 200 ja 1000 mg kuparia tai nikkeliä kahta maalitraa kohti. Vertailumaana oli Maatalouden tutkimuskeskuksen Etelä-Pohjanmaan tutkimusasemalta (EPO) noudettu saastumaton savimaa, joka samojen raskasmetallilisäysten lisäksi kalkittiin.

Kasvilajien raskasmetallipitoisuudet olivat erisuuria. Myös eri koepaikoilla kasvaneen kasvin raskasmetallipitoisuudet vaihtelivat selvästi. Vehnän jyvien kupari- ja lyijypitoisuudet olivat pieniä kaikilla koepaikoilla. Nikkeli kertyi kasveihin helposti ilmalaskeumasta. Myös kupari ja kadmium siirtyivät helpohkosti ilmasta kasveihin.

Astiakokeessa nikkeli oli kuparia myrkyllisempi kauralle. Happamassa EPO-maassa pienehköt nikkelija kuparipitoisuudet, $\mathrm{Ni} 20 \mathrm{mg}$ ja $\mathrm{Cu} 100 \mathrm{mg}$ maalitraa kohti, pienensivät kauran versojen satoa. EPOmaan kalkitseminen pienensi selvästi nikkelin ja kuparin myrkyllisyyttä. Pahimmin saastuneessa Harjavallan maassa pienin kuparilisäys, Cu $20 \mathrm{mg}$ maalitraa kohti, pienensi ohran versojen satoa. Harjavallassa saattaakin olla happamia viljelymaita, joissa maan korkea kuparipitoisuus voi vähentää kasvien kasvua. 